\title{
Imperfect Alternatives: Institutional Choice and the Reform of INVESTMENT LAW
}

\author{
By Sergio Puig and Gregory Shaffer*
}

\section{ABSTRACT}

This Article applies the theory of comparative institutional analysis to evaluate the trade-offs associated with alternative mechanisms for resolving investment disputes. We assess the tradeoffs in light of the principle of accountability under the rule of law, which underpins the goals of fairness, efficiency, and peace that are attributed to investment law. The Article makes two recommendations: first, reforms should address complementarity between domestic and international institutions; second, institutional choices should respond to the different contexts that states face.

The tide is turning. Ferment is in the air. Reform or even transformation of foreign direct investment governance appears on the way. ${ }^{1}$ Different proposals are advanced, different proposals trashed. Some defend the current arbitral system of investor-state dispute settlement (ISDS). Others support the alternative of a multilateral investment court system. Some focus on market mechanisms. Others on national sovereignty. What we lack is a framework for comparatively assessing the range of institutional alternatives in light of their relative tradeoffs. ${ }^{2}$ This Article provides such a framework. Our central claim is that all institutional alternatives are highly imperfect because of the dynamics of participation within them, and thus criticism of one institutional alternative without comparatively assessing the imperfections of real-life alternatives is of little help and can make for bad public policy.

To assess trade-offs, one should address two issues in parallel: goal choice and institutional choice. Scholars commonly start by specifying the goals of international law. ${ }^{3}$ Law-and-economics scholars focus on efficiency. ${ }^{4}$ Rawlsian-oriented scholars focus on

\footnotetext{
* Sergio Puig is Associate Professor, James E. Rogers College of Law, University of Arizona; Gregory Shaffer is Chancellor's Professor, University of California, Irvine School of Law. We thank Anne van Aaken, Julian Arato, Jonnathan Bonnitcha, Tomer Broude, Andrew Coan, Seth Davis, Frank Garcia, David Gantz, Neil Komesar, Karen Knopp, Nico Krisch, Dan Magraw, Mona Pinchis, Anthea Roberts, David Schneidermann, Alec Stone Sweet, Ingrid Wuerth, Jason Yackee, the ASIL editors, and the anonymous reviewers for their comments.

${ }^{1}$ Anthea Roberts, Incremental, Systemic and Paradigmatic Reform of Investor-State Arbitration, 113 AJIL 412 (2018)

${ }^{2}$ See generally Neil K. Komesar, Imperfect Alternatives: Choosing Institutions In Law, Economics, And Public Policy (1994) (Our title intentionally borrows from this book.).

${ }^{3}$ See, e.g., Yuval Shany, Assessing the Effectiveness of International Courts: A Goal-Based Approach, 106 AJIL 225 (2012) (applying a goal-based approach to assessing the effectiveness of international courts).

${ }^{4}$ See e e.g., Richard A. Posner, Economic Analysis Of Law $\$ 19.2$, at 532-33 (6th ed. 2003). For its application in trade international law, see Warren F. Schwartz \& Alan O. Sykes, The Economic Structure of Renegotiation and Dispute Resolution in the World Trade Organization, 31 J. LEGAL STUD. 179, 181 (2002) ("the WTO provisions
} 
fairness. ${ }^{5}$ And realist-oriented ones focus on interstate relations, power, and conflict. ${ }^{6}$ For international investment law, commentators conventionally describe these goals as fairness, resource allocation efficiency, and peace. They stress the goals in different ways, but they have all been fundamental in contests over the construction of the international investment law regime and its institutions over time. ${ }^{7}$ We recast these three goals in light of the broader principle of accountability under the rule of law, which underpins (or, we argue, should underpin) these goals.

Inevitably, observers will disagree over how to specify goals and theorize justice. We argue that, whatever one's preferred goal, different institutional processes will mediate the pursuit of that goal in highly imperfect ways. All institutional processes are imperfect, and all of them are imperfect in different ways given the dynamics of participation within them. These dynamics result in different minoritarian and majoritarian biases. Institutional choice is thus required, and to make such choices, one needs to compare institutional processes.

After applying the comparative institutional analytic framework to a range of market, political, and judicial options for resolving investment disputes, we conclude with two recommendations. First, policymakers and scholars should pay greater heed to the place of institutional complementarity in support of the rule of law in domestic jurisdictions as a central consideration of the international investment regime. The argument for complementarity is that, where possible, international processes should be structured not as substitutes but as complements to domestic processes to assure government accountability. Second, policymakers and scholars should recognize that countries face a range of contexts-in terms of capital endowment, market size, ideology, institutional development, and historical legacy—and that these contexts will affect their institutional choice.

The Article proceeds in five parts. Part I briefly presents the historical backdrop of investment regulation and dispute settlement, from its early roots to the setting of contemporary debates over institutional reform. Part II examines three conventional normative goals for investment protection: fairness, efficiency, and peace. It then frames them in light of the overarching principle of accountability under the rule of law. Part III presents the comparative institutional analytic framework with its focus on the dynamics of participation in institutional processes so that trade-offs among institutional choices are assessed. Part IV applies the framework to evaluate different market, political, and judicial alternatives for handling international investment disputes. Part $\mathrm{V}$ concludes regarding the choice of options available given the different contexts states face.

respecting renegotiation and the settlement of disputes over breach of obligations are carefully designed to facilitate efficient adjustments to unanticipated circumstances").

${ }^{5}$ See, e.g., Aaron James, Fairness in Practice: A Social Contract for a Global Economy (2012); Thomas M. Franck, Fairness In International Law And Institutions (1995).

${ }^{6}$ See, e.g. Joseph M. Grieco, Cooperation Among Nations: Europe, America And Non-tarifF Barriers To TRADE (1990) (noting that realists believe that international cooperation in trade is governed by power); STEVEN R. Ratner, The Thin Justice of International Law: A Moral Reckoning of The LaW of Nations (2015) (focusing first on the "pillar of peace" in terms of the absence of armed conflict).

7 See Sergio Puig, Recasting ICSID's Legitimacy Debate: Towards a Goal-Based Empirical Agenda, 36 FordHAm INT'L L.J. 465 (2013) (discussing the different goals of investment law). 


\section{A New Debate in Investment LaW}

\section{A. Emergence and Evolution of ISDS}

Conflict over governmental treatment of property held by foreign nationals has existed for centuries, but it intensified in the seventeenth century with the rise of states and imperial, mercantilist competition among them. ${ }^{8}$ To resolve conflicts, states turned to some of the methods still used today, such as negotiation and mediation, as well as others that are no longer permissible, such as armed intervention and the hiring of privateers to collect debts. ${ }^{9}$

States submitted foreign investment conflicts to international adjudication as early as 1794, when mixed arbitral commissions under the Jay Treaty addressed the settlement of debts to British creditors. ${ }^{10}$ Over time, multiple commissions and ad hoc tribunals were formed. They developed international investment law in the shadow of state power and coercion, finding the law's sources in customary international law and general principles of law. ${ }^{11}$

After World War II, industrialized countries tried to formalize their views of investment law in treaties. ${ }^{12}$ The United States, for example, promoted treaties of Friendship, Commerce, and Navigation (FCN treaties) with its allies. ${ }^{13}$ Under some FCN treaties, states could invoke interstate dispute settlement (including before the International Court of Justice (ICJ)) by offering diplomatic protection after their nationals had exhausted local remedies. ${ }^{14}$

During the Post-War years, the United States and Western European countries increasingly called for multilateral initiatives that would protect their and their nationals' property in newly decolonized territories. ${ }^{15}$ Developing countries resisted these attempts by pioneering a countervailing effort to create a New International Economic Order that recognized their sovereign ownership of their natural resources and championed the exclusive use of domestic

8 See Kate Miles, The Origins of International Investment Law: Empire, Environment and the SAFEguarding of CAPITAL (2013).

${ }^{9}$ See Grover Clark, The English Practice with Regard to Reprisals by Private Persons, 27 AJIL 694, 695-96 (1933); Yves de la Briere, Évolution de la doctrine et de la pratique en matière de représailles, 22 RECUEIL DE COURS 252, 258 (1928).

${ }^{10}$ Treaty of Amity, Commerce and Navigation, United States-Great Britain, Nov. 19, 1794, 8 Stat. 116. See also Barton Legum, Federalism, NAFTA Chapter Eleven and the Jay Treaty of 1794, 95 ASIL PrOC. 202 (2001).

${ }^{11}$ Tzvika Alan Nissel, A History of State Responsibility: The Struggle for International Standards (18701960), ch. 3, 130-65 (2016) (unpublished LLD dissertation, Helsinki University); Jason Webb Yackee, The First Investor-State Arbitration: The Suez Canal Company v Egypt (1864), 17 J. World INV. \& Trade 401 (2016). See also Charles Lipson, Standing Guard: Protecting Foreign Capital in the Nineteenth and Twentieth Centuries (1985).

${ }^{12}$ Kenneth J. Vandevelde, A Brief History of International Investment Agreements, 12 U.C. DAVIS J. INT'L L. \& POL'y 157, 168-70 (2005) (providing a detailed history of investment agreements and discussing their emergence and the threat of uncompensated expropriations of investments).

${ }^{13}$ Herman Walker, Jr., Modern Treaties of Friendship, Commerce, and Navigation, 42 MinN. L. REV. 805, 805 (1958); John F. Coyle, The Treaty of Friendship, Commerce and Navigation in the Modern Era, 51 Colum. J. Transnat'L L. 302, 308 (2013) ("between 1946 and 1968, the United States negotiated more than twenty $[\mathrm{FCN}]$ agreements").

${ }^{14}$ See, e.g., Treaty of Friendship, Commerce and Navigation, United States-Italy, Feb. 2, 1948, 63 Stat. 2255, TIAS No. 1965; Treaty of Amity and Economic Relations, United States-Vietnam, Apr. 3, 1961, 12 UST 1703, TIAS No. 4890; Treaty of Friendship, Commerce and Navigation, United States-Nicaragua, Jan. 21, 1956, 9 UST 449, TIAS No. 4024.

${ }^{15}$ See, e.g., The Proposed Convention to Protect Private Foreign Investment: A Round Table, 9 J. PUB. L. 115, 119$24(1960)$ 
law and institutions. ${ }^{16}$ As a result of this clash of perspectives, multilateral treaty-making initiatives addressing substantive rights owed to foreign investors - then a highly contested matter-went nowhere. ${ }^{17}$ However, the negotiation of the Convention on the Settlement of Investment Disputes Between States and Nationals of Other States proceeded, which created a mechanism for the use of ad hoc tribunals to enforce investment commitments that might be separately made through domestic law, contract, or treaty. ${ }^{18}$ This convention created the International Centre for Settlement of Investment Disputes (ICSID)—an international organization that is part of the World Bank Group. ${ }^{19}$

ICSID had a slow start, administering mostly contractual disputes between foreign investors and states. ${ }^{20} \mathrm{~A}$ more favorable climate toward foreign direct investment developed, abetted by the fall of the Berlin Wall, the collapse of the Soviet Union, and the rise of the "Washington Consensus" for development policy. ${ }^{21}$ This conjunction catalyzed the negotiation of scores of bilateral investment treaties (BITs) containing ISDS, followed by increased litigation under them. ${ }^{22}$ Through these BITs, investors could bring claims without the need for home state espousal or (in most cases) the exhaustion of local remedies. Developing countries signed these treaties in the hope of attracting investment and to reduce outside political interference, ${ }^{23}$ but often with limited information regarding their implications. ${ }^{24}$

A dramatic rise in ISDS cases based on BITs generated a backlash against ISDS, which intensified following the 2007 global financial crisis and the filing of politically charged

${ }^{16}$ Declaration on the Establishment of a New International Economic Order, GA Res. 3201 (S-VI), UN GAOR, 29th Sess., Supp. No. 1, UN Doc. A/Res/3201(S-VI) (May 1, 1974). See also Burns H. Weston, The Charter of Economic Rights and Duties of States and the Deprivation of Foreign-Owned Wealth, 75 AJIL 437, 439 (1981).

${ }^{17}$ See, e.g., the abandonment of the Draft Convention on Investments Abroad (1959), available at http:// unctad.org/Sections/dite_tobedeleted/iia/docs/compendium/en/137\%20volume\%205.pdf. For an earlier effort, see The Draft Convention on the Treatment of Foreigners (1928), League of Nations, Document C. 174. M. 53. 1928.

${ }^{18}$ Report of the Executive Directors of the International Bank for Reconstruction and Development on the Convention on the Settlement of Investment Disputes Between States and Nationals of Other States, 1 ICSID REP., paras. 23-25 (1993).

${ }^{19}$ Convention on the Settlement of Investment Disputes Between States and Nationals of Other States, Mar. 18, 1965, 17 UST 1290, 575 UNTS 192 [hereinafter ICSID Convention].

${ }^{20}$ Rudolf Dolzer \& Christoph Schreuer, Principles of International Investment Law 224 (2008) (describing low intake of mostly contract-based cases); ANTONio R. PARrA, The History of ICSID 66-67 (2012)

${ }^{21}$ See John Williamson, The Strange History of the Washington Consensus, 27 J. POst KeYnesIan Econ. 195 (2004).

${ }^{2}$ See, e.g., Joachim Pohl, Kekeletso Mashigo \& Alexis Nohen, Dispute Settlement Provisions in International Investment Agreements: A Large Sample Survey (OECD Investment Division, OECD Working Paper on International Investment, No. 2012/2, 2012), available at http://www.oecd.org/daf/investment/workingpapers (estimating that $93 \%$ of BITs contain language on ISDS, based on a sample of 1,660 treaties).

${ }^{23}$ UN Conference on Trade \& Dev., Dispute Settlement: Investor-State, at 13, UN Doc. UNCTAD/ITE/IIT/30 (2003) ("[T]he willingness to accept internationalized dispute settlement on the part of the host country may well be motivated by a desire to show commitment to the creation of a good investment climate."); Ecuador v. United States, Expert Opinion with Respect to Jurisdiction of Professor W. Michael Reisman, para. 54 (Perm. Ct. Arb. Apr. 24, 2012).

24 Lauge Skovgaard Poulsen, Bounded Rationality and Economic Diplomacy: The Politics of Investment Treaties in Developing Countries (2015). See, e.g., Republic of South Africa, Bilateral Investment Treaty Policy Framework Review: Government Position Paper 5 (June 2009), available at http:// www.pmg.org.za/files/docs/090626trade-bi-lateralpolicy.pdf (suggesting changes to BITs because they "were not in [its] long term interest" and "the risks posed by such treaties were not fully appreciated at that time"). 
cases implicating developed countries' public policies. ${ }^{25}$ The total number of ISDS cases is unknown because arbitrations may be kept confidential, but the United Nations Conference on Trade and Development (UNCTAD) reports that as of July 31, 2017, there have been 817 publicly known ISDS cases, with 77 of them being filed in 2015 alone. ${ }^{26}$ Investors from Europe and North America have largely brought these claims, which have involved at least 114 countries as respondents. ${ }^{27}$ Many scholars and NGOs contended that ISDS developed from coercive origins, reflects asymmetric power differentials, and, as a result, is unfair, imbalanced, and illegitimate. ${ }^{28}$ Although other scholars contested these depictions, ${ }^{29}$ the media often adopted this frame, emphasizing ISDS's undemocratic and highly clandestine nature. ${ }^{30}$

Governments responded to these criticisms and the risk of significant liability from large ISDS awards. In the last decade, countries have terminated BITs with ISDS clauses (such as Ecuador, Indonesia, and South Africa), withdrew from the ICSID Convention (notably, Bolivia, Ecuador, and Venezuela), threatened to leave it (including Argentina, El Salvador, and Nicaragua), or created new constraints on using ISDS (such as Norway and New Zealand). ${ }^{31}$ In response to this backlash, multiple reform proposals gradually emerged and

\footnotetext{
25 Gus Van Harten, Investment Treaty Arbitration and Public Law (2008); Mattias Kumm, An Empire of Capital? Transatlantic Investment Protection as the Institutionalization of Unjustified Privilege, 4 ESIL REFLECTION 3 (2015). For controversial cases, see, e.g., Vattenfall AB v. Fed. Republic of Ger., ICSID Case No. ARB/09/6, Claimant's Request for Arbitration (Mar. 30, 2009), available at https://www.italaw.com/sites/default/files/ case-documents/ita0889.pdf; Philip Morris Asia Ltd. v. Austl., PCA Case No. 2012-12, Award on Jurisdiction and Admissibility (UNCITRAL Dec. 17, 2015), available at http://www.italaw.com/sites/default/files/case-documents/italaw7303_0.pdf.

${ }^{26}$ UNCTAD, Special Update on Investor-State Dispute Settlement: Facts and Figures, UNCTAD/DIAE/PCB/2017/7 (Nov. 2017) available at http://unctad.org/en/PublicationsLibrary/diaepcb2017d7_en.pdf.

${ }^{27} \mathrm{Id}$.

${ }^{28}$ See, e.g., David Schneiderman, Constitutionalizing Economic Globalization: Investment Rules And Democracy's Promise 225 (2008) (arguing that the protection offered to foreign investors under international investment law "destabilize[s] the functioning of democratic processes, represented by other constitutional rules"); M. Sornarajah, The International LaW on Foreign Investment 1-30 (4th ed. 2017); Alliance for Justice, Letter to US Congressional Officials and US Trade Representative (Mar. 11, 2015), available at http://bit. ly/1GKLy5Q. See generally The Backlash Against InVestment Arbitration: Perceptions and Reality (Michael Waibel, Asha Kaushal, Kyo-Hwa Chung \& Claire Balchin eds., 2010) (identifying some of the systemic concerns, such as limitations on domestic policy space, a lack of democratic accountability, a systemic pro-investor bias, and the inability of treaties to respond to changes in economic circumstances).

${ }^{29}$ See, e.g., Charles N. Brower \& Stephan W. Schill, Is Arbitration a Threat or a Boon to the Legitimacy of International Investment Law?, 9 CHI. J. INT'L L. 471, 477 (2009) (defending ISDS for the capacity to "stabiliz[e]" investor expectations through the enforcement of rules).

${ }^{30}$ Philip Morris Sues Australia Over Cigarette Packaging, N.Y. Times, June 26, 2011, at B8; Charlie Fidelman, Maker of Herbicide Sues Quebec; Dow Agrosciences Says Province Has No Scientific Basis for Ban, MonTREAL GazetTe, Apr. 14, 2009, at A10. James Surowiecki, The Case Against Obama's Trade Agreements, THE New Yorker (June 22, 2015).

${ }^{31}$ Ignacio A. Vincentelli, The Uncertain Future of ICSID in Latin America, 16 LAw \& Bus. REv. AM. 409, 410 (2010) (discussing withdrawals from ICSID by Bolivia, Ecuador, and Venezuela). Ecuador and Venezuela sought to renegotiate a number of their investment treaties. See United Nation Conference on Trade \& Development, Recent Developments in International Investment Agreements (2007-June 2008), 2 IIA Monitor 6 (2008). South Africa suspended negotiations of investment treaties. See, e.g., Republic of South Africa, Bilateral Investment Treaty Policy Framework Review: Government Position Paper 12, at 12 (2009), available at http:// www.pmg.org.za/files/docs/090626trade-bi-lateralpolicy.pdf; Luke Eric Peterson, South Africa Pushes Phase-Out of Early Bilateral Investment Treaties After at Least Two Separate Brushes with Investor-State Arbitration, INV. ARB. ReP. (Sept. 23, 2012), at http://www.iareporter.com/articles/ 20120924_1. Others have imposed new restrictions: Damon Vis Dunbar, Norway Shelves Its Draft Model Bilateral Investment Treaty, InV. Treaty News (June 8, 2009), at https://www.iisd.org/itn/2009/06/08/norway-shelves-its-proposed-model-bilateral-investment-treaty;
} 
many states created new model BITs (e.g., Canada and the United States) or approaches (e.g., the European Union). ${ }^{32}$

\section{B. Challenges to the Current ISDS Model}

For many commentators, the main problem with the current system of international investment law enforcement is that it is based on a model of international commercial arbitration. It relies on ad hoc tribunals of party-appointed arbitrators to resolve one-off disputes, even though the disputes may involve public law and policy. ${ }^{33}$ The tribunals interpret vague treaty rules-such as provisions demanding "fair and equitable treatment" and prohibitions against "measures tantamount to expropriation." The system lacks an appeal process, other than a narrow annulment proceeding that has been routinely criticized. ${ }^{34}$ Conflicting decisions, sometimes involving the same facts, raise rule-of-law and coherence concerns. ${ }^{35}$ Because the arbitrators are appointed on an ad hoc basis as opposed to a fixed term and are allowed to represent clients in other arbitrations (conduct known as "double hatting"), they face incentives to decide cases in a manner that favors the party that appointed them and to assure a flow of future cases, sparking challenges to their independence and impartiality. ${ }^{36}$ Collectively, these individuals constitute a small club of self-regulated decision-makers that lacks gender and geographic diversity. ${ }^{37}$ Given the potential for large damage awards, the threat of litigation, it is contended, can chill regulation. ${ }^{38}$

ASEAN Australia-New Zealand FTA, ch. 11, Art. 27(2) ("The tribunal shall, on its own account or at the request of a disputing party, request a joint interpretation of any provision of this Agreement. ..")

32 Roberts, supra note 1 , at 416.

${ }^{33}$ Gus Van Harten \& Martin Loughlin, Investment Treaty Arbitration as a Species of Global Administrative Law, 17 Eur. J. InT'L L. 121, 131-33 (2006); Anthea Roberts, Clash of Paradigms: Actors and Analogies Shaping the Investment Treaty System, 107 AJIL 45, 92 (2013) (discussing criticism of ISDS proposing a new theoretical framework to explain the investment treaty system).

${ }^{34}$ ICSID Convention, supra note 19, Art. 52(1) (limiting annulment review to challenges claiming that the Tribunal "manifestly exceeded its powers," was subject to "corruption," or "failed to state the reasons" for its decision). On criticism of the annulment system, see W. Michael Reisman, The Breakdown of the Control Mechanism in ICSID Arbitration, 1988 DuKE L.J. 739, 787 (1989). On inconsistent application of review standards, see Dohyun Kim, The Annulment Committee's Role in Multiplying Inconsistency in ICSID Arbitration: The Need to Move Away from an Annulment-Based System, 86 N.Y.U. L. REV. 242, 243 (2011).

${ }^{35}$ One can give numerous examples, but just to start, cf. Cont'l Cas. Co. v. Arg. Republic, ICSID Case No. ARB/03/9, Award, paras. 189-230 (Sept. 5, 2008), with Enron Corp. \& Ponderosa Assets, L.P. v. Arg. Republic, ICSID Case No. ARB/01/3, Award, paras. 322-45 (May 22, 2007); and Ronald S. Lauder v. Czech Republic, Final Award (UNCITRAL Sept. 3, 2001), with CME Czech Republic B.V. (Neth.) v. Czech Republic, Final Award (UNCITRAL Mar. 14, 2003). Cf. Susan D. Franck, The Legitimacy Crisis in Investment Treaty Arbitration: Privatizing Public International Law Through Inconsistent Decisions, 73 FordHAm L. ReV. 1521 (2005), and Jan Paulsson, Avoiding Unintended Consequences, in Appeals MeChanisms in InternationaL Investment Disputes 241, 258-59 (Karl Sauvant with Michael Chiswick-Patterson ed., 2008) (suggesting that concerns about inconsistency are overblown).

${ }^{36}$ Malcolm Langford, Daniel Behn \& Runar Hilleren Lie, The Revolving Door in International Investment Arbitration, 20 J. INT'L ECO. L. 301 (2017) (on double-hatting); Sergio Puig, Blinding International Justice, 56 VA. J. INT'L L. 647, 661, 672-75 (2017) (explaining different forms of bias in ISDS).

${ }^{37}$ Gus Van Harten, The (Lack of) Women Arbitrators in Investment Treaty Arbitration, Colum. FDI PERSPS. NO. 59 (Feb. 6, 2012), available at http://ccsi.columbia.edu/files/2014/01/FDI_59.pdf (at that time, out of 631 appointments in 249 known cases, only 41 of appointments were women).

38 See Kyla Tienhaara, Regulatory Chill and the Threat of Arbitration: A View from Political Science, in EvOLUTION In Investment Treaty Law And Arbitration 606, 606 (Chester Brown \& Kate Miles eds., 2011) (arguing that regulatory chill is an important problem "inadequately addressed and often prematurely dismissed by legal scholars"). 
In response to these critiques, states and commentators have proposed a range of institutional reforms that are being discussed in a working group of the United Nations Conference on International Trade Law (UNCITRAL). ${ }^{39}$ Prominently, the European Union (EU) has promoted a multilateral investment court system where private investors retain standing to file claims directly against states. At its core, this "systemic" change would create a tribunal of first instance and an appellate body, with the judges having fixed terms, paid a regular salary, and selected on a random basis from a roster designated by states. ${ }^{40}$ These judges accordingly would be restricted from acting as counsel in other cases. The European Union has already concluded agreements containing such a system—designed for bilateral relations, but including flexibilities for multilateralization — with Canada, Singapore, Vietnam, and Mexico, and indications that more agreements with these features will follow. ${ }^{41}$ As one of the world's largest senders and receivers of foreign direct investment and given that around half of all existing BITs involve EU members, the European Union exercises considerable leverage in this reform process. ${ }^{42}$

In contrast, Brazil and South Africa have proposed alternatives involving mediation, possibly backed by state-to-state adjudication in which the state decides whether to espouse an investor's claims. ${ }^{43}$ In parallel, India adopted a new model BIT that, while it incorporates ISDS, conditions its use on the initial pursuit of remedies before domestic courts for at least five years. ${ }^{44}$ India and China also have signaled interest in an appellate process, similar to that included in the EU's proposal. ${ }^{45}$ While the United States previously defended ISDS, in October 2017, Robert Lighthizer, the United States Trade Representative (USTR), signaled a potential shift in the U.S. position regarding ISDS, suggesting that investors should

${ }^{39}$ Roberts, supra note 1 , at 415-18

${ }^{40}$ European Commission, Investment in TTIP and Beyond-The Path for Reform, Enhancing the Right to Regulate and Moving from Current ad hoc Arbitration Towards an Investment Court, at 11 (May 2015), available at http://trade.ec.europa.eu/doclib/docs/2015/may/tradoc_153408.PDF ("the EU should pursue the creation of one permanent court" and offering some details).

${ }^{41}$ See generally Colin M. Brown, A Multilateral Mechanism for the Settlement of Investment Disputes. Some Preliminary Sketches, 32 ICSID REV.-FOR. INV. L.J. 673, 682 (2017) ("The EU is currently engaging on a similar basis with all of its negotiating partners (Viet Nam, Singapore, Japan, the United States, China, Myanmar, Indonesia, Malaysia, Mexico etc.)."). See also Joint Interpretative Instrument on the Comprehensive Economic and Trade Agreement (CETA) Between Canada and the European Union and its Member States, OJ L 11, 14 (Jan. 2017) [hereinafter CETA]; European Commission Press Release, The EU and Vietnam Finalize Landmark Trade Deal (Dec. 2, 2015), at http://trade.ec.europa.eu/doclib/press/ index.cfm?id=1409; European Commission Press Release, EU and Mexico Reach New Agreement on Trade (Apr. 21, 2018), at http://trade.ec.europa.eu/doclib/press/index.cfm?id=1830 ("the agreement . . includes the EU's new Investment Court System").

42 UNCTAD, World Investment Report 2015. Reforming International Investment Governance, at xi, 5-8 (May 2015), available at http://unctad.org/en/PublicationsLibrary/wir2015_en.pdf.

${ }^{43}$ Brazil Model Cooperation and Facilitation Investment Agreement 2015, Art. 23-4 available at http://investmentpolicyhub.unctad.org/Download/TreatyFile/4786. For discussion, see Fabio Morosini \& Michelle Ratton Sanchez Badin, Reconceptualizing International Investment Law from the Global South, in RECONCEPTUALIZING Investment LaW from the Global South (Fabio Morosini \& Michelle Ratton Sanchez Badin eds., 2017); South Africa Protection of Investment Act 22 of 2015, Art. 13.5 (Dec. 15, 2015), available at https://www. thedti.gov.za/gazzettes/39514.pdf ("The government may consent to [State-to-State] arbitration in respect of investments covered by this Act, subject to the exhaustion of domestic remedies.").

${ }^{44}$ Model Text for the Indian Bilateral Investment Treaty 2016, Art. 15.2, available at http://mof.gov.in/ reports/ModelTextIndia_BIT.pdf (establishing that before seeking international arbitration, investors must seek justice before local authorities for at least five years).

${ }^{45}$ For India, see id. Art. 29. For China, see, Roberts, supra note 1, at 417, 422. 
rely on market mechanisms, such as political risk insurance. ${ }^{46}$ In this context, the ICSID Secretariat also has advanced consideration of an incremental updating of the ICSID Regulations and Rules. ${ }^{47}$

Much of the debate in the United States and Europe has focused on assessing whether the European Union's proposed multilateral investment court system constitutes an improvement or even a significant change. ${ }^{48}$ The European Union's reform proposal and ISDS, however, are just two alternative adjudicatory forms. Other adjudicatory and non-adjudicatory options exist, including market-oriented mechanisms such as insurance and contract. Thus, the broader question arises: What are the relative trade-offs among different market, political, and judicial institutional alternatives for addressing investment disputes?

\section{Normative Goals of InVEstment LaW}

To assess institutional options comparatively, we first examine three goals that have been advanced to justify the current ISDS model: fairness, resource allocation efficiency, and peace. We reconstruct these goals to place them in their best light in terms of justification and fit from a perspective of reflective equilibrium. ${ }^{49}$ As an increasing number of countries are both senders and receivers of foreign direct investment, a greater number operate under a veil of ignorance as to whether they could be claimants or respondents in investment disputes. This trend is conducive to an approach that is more balanced in terms of the characterization of investment law goals, which we argue has developed over the past decade. We address these goals in three subsections in which we build our argument from policymaker statements and ISDS jurisprudence as they have developed, and (in doing so) we explain why a one-sided view of fairness, efficiency, and peace from the perspectives of the investor and investment promotion is flawed (although supported in early ISDS jurisprudence and policymaker statements). We then reframe these goals in terms of a single, overarching, umbrella principle that we contend encompasses them analytically and is conducive to their achievement consequentially-accountability under the rule of law.

\footnotetext{
${ }^{46}$ Shawn Donnan, NAFTA: Bitter Differences over Nafta Break into the Open, Fin. Times (Oct. 18, 2017), at https://www.ft.com/content/058aa538-b387-11e7-a398-73d59db9e399 ("Mr Lighthizer ... said the [ISDS] system amounted to an unfair subsidy for businesses to invest overseas. "Why is it my job to encourage people to invest in Mexico?"”).

${ }^{47}$ ICSID, Amendment of ICSID's Rules and Regulations, at https://icsid.worldbank.org/en/Pages/about/ Amendment-of-ICSID-Rules-and-Regulations.aspx ("ICSID launched the current amendment process in October 2016 and invited Member States to suggest topics that merited consideration. In January 2017, ICSID issued a similar invitation to the public inviting suggestions for rule amendments."). Roberts, supra note 1 , at 419.

${ }^{48}$ Cf. Stephen Schwebel, The Proposals of the European Commission for Investment Protection and an Investment Court System, ISDS BLOG (May 17, 2016), available at http://isdsblog.com/wp-content/uploads/sites/2/2016/05/ THEPROPOSALSOFTHEEUROPEANCOMMISSION.pdf; Charles Brower \& Sadie Blanchard, What's in a Meme? The Truth about Investor-State Arbitration: Why it Need Not, and Must Not, Be Repossessed by States, 52 Columb. J. Transnat'l L 689 (2014); UN Office of the High Commissioner for Human Rights Press Release, Statement by the Independent Expert on the Promotion of a Democratic and Equitable International Order (Feb. 4, 2016), at www.ohchr.org/EN/NewsEvents/Pages/DisplayNews.aspx?NewsID=17005\&LangID= F\#sthash.CLxvTf94.dpuf ("the investment Court System is but an extension of ISDS, which suffers from many of the same fundamental flaws").

49 See John Rawls, A Theory of Justice 18 (rev. ed. 1971, 1999) (on reflective equilibrium); Ronald DWORKIN, LAW'S EMPIRE 52 (1986) (on constructive interpretation).
} 


\section{A. Fairness}

A first commonly expressed goal of the ISDS system, as advocated by its defenders, is fairness. ${ }^{50}$ ISDS, it is contended, provides access to justice for aggrieved investors claiming unfair treatment. ${ }^{51}$ From this perspective, ISDS provides a readily available, neutral, adjudicatory alternative for investors who are unable to obtain justice before national institutions that are politically subservient or biased. ${ }^{52}$ The creation of the ISDS system through ICSID supported this aim. ICSID stressed the goal of fairness as a "paramount objective" through which it can make a "real contribution ... in restoring the climate of mutual confidence between states and investors." 53

It is commonly argued, in stylized fashion, that the investor faces what law-and-economics scholars refer to as a time inconsistency or "hold-up" problem. In essence, the investor may have bargaining power when it makes the investment, but that bargaining power diminishes after it invests capital that it cannot easily and quickly withdraw when conditions deteriorate. ${ }^{54}$ As ISDS arbitrator and scholar Michael Reisman writes,

A common feature of foreign direct investment is that the investor has sunk substantial capital in the host State... [such that] parity will cease and things will tilt heavily in favor of the respondent State. Unless, that is, both sides appreciate that if negotiations fail, compulsory arbitration will follow. ${ }^{55}$

Many tribunals, especially earlier in their development of ISDS jurisprudence, focused on fairness toward foreign investors. In this vein, the tribunal in the case Pope \& Talbot v. Canada stated that " $[\mathrm{t}]$ he aim of [the North American Free Trade Agreement (NAFTA)] seems to be. . . to present to investors the kind of hospitable climate that would insulate them from political risks or incidents of unfair treatment." ${ }^{56}$ In the words of the Corn Products v. Mexico tribunal (with former ICJ Judge Greenwood presiding), the focus of ISDS is on the "investor . . . seeking to enforce what it asserts are its own rights under the treaty." 57

\footnotetext{
${ }^{50}$ Fairness generally refers both to fair treatment substantively (such as in terms of a "minimal standard of treatment" or "fair and equitable treatment") and procedurally (such as in terms of access to justice to defend substantive claims), recognizing the rights of both investors and treaty parties. Our primary focus is on procedural fairness since this Article assesses alternative institutional mechanisms of dispute settlement. Our broader point is that institutional choice affects substantive outcomes, including through interpretation, so that procedural and substantive fairness are linked.

${ }^{51}$ See, e.g., Robert Volterra, International Law Commission Articles on State Responsibility and Investor-State Arbitration: Do Investors Have Rights?, 25 ICSID ReV.-For. Inv. L.J. 218, 220 (2010).

52 See, e.g., Jan Paulsson, Denial Of Justice In International Law 149 (2005) ("Whatever the rosy rhetoric about the equality of treatment of nationals and foreigners, the very fact of being foreign creates an inequality. The foreigner's obvious handicap-his lack of citizenship—is usually compounded by vulnerabilities with respect to many types of influence: political, social, cultural.").

53 ICSID, ANNUAL RePort, at 4 (1985).

${ }^{54}$ Yeon-Koo Che \& Jozsef Sakovics, A Dynamic Theory of Holdup, 72 Econometrica 1063 (2004).

${ }^{55}$ W. Michael Reisman, International Investment Arbitration and ADR: Married but Best Living Apart, 24 ICSID Rev.-For. Inv. L.J. 185, 190-91 (2009) (emphasis in original). See also Stephen J. Kobrin, Testing the Bargaining Hypothesis in the Manufacturing Sector in Developing Countries, 41 INT'L ORG. 609 (1987) (providing some earlier empirical evidence).

${ }^{56}$ Pope \& Talbot Inc. v. The Government of Canada, Award on the Merits of Phase 2, para. 116 (NAFTA Apr. 10, 2001).

${ }^{57}$ Corn Products International, Inc. v. United Mexican States, ICSID Case No. ARB(AF)/04/01, Decision on Responsibility, para. 174 (Jan. 15, 2008).
} 
However, since around the mid-2000s, ISDS decisions increasingly recognize that fairness should not be viewed in one-sided terms focusing only on the foreign investor, given that the state has a responsibility to balance other welfare goals with the protection of investment. ${ }^{58}$ Tribunals' development of the principle of a state's "right to regulate" in light of social welfare goals reflects a broader concern of fairness toward other stakeholders. ${ }^{59}$ Tribunals thus generally "balance" investor rights and other claims affecting social welfare. ${ }^{60}$ When they do so, they implicitly recognize that representative governments should take into account the interests of other stakeholders as well when they make decisions that can affect investors. This development is captured in some contemporary BITs, ${ }^{61}$ including the preamble of the Comprehensive Economic and Trade Agreement (CETA), which references the protection of "investments and investors" with "the right of the Parties to regulate in the public interest," and the 2012 U.S. model BIT, which includes the "objective[]" of consistency "with the protection of health, safety, and the environment, and the promotion of internationally recognized labor rights." 62

Given the lack of an appellate mechanism in ISDS and the contentiousness of commentary, debates continue regarding the conceptualization of fairness. Many contend-and we agree-that limiting the concept of fairness to apply only to foreign investors is itself unbalanced and asymmetric, and thus unfair. ${ }^{63}$ Such asymmetry has raised questions regarding the evenhandedness of ISDS, and thus of the international rule of law. Some contend that BITs should be revised to create explicit obligations for investors and the right to sue investors for breaching those obligations; indeed, some new BITs include

\footnotetext{
${ }^{58}$ See Alec Stone Sweet, Michael Yunsuck Chung \& Adam Saltzman, Arbitral Lawmaking and State Power: An Empirical Analysis of Investment Arbitration, 7 J. INT'L Disp. SetTlement 1, 16-17 (2017) [hereinafter Arbitral Lawmaking] ("As tribunals from Saluka forward have made clear, investors cannot expect regulatory arrangements to be frozen."); Alec Stone Sweet \& Florian Grisel, The Evolution of International Arbitration: JudicializATION, GovernanCE, LegitimaCy 190 (2017) ("in the vast majority of awards, tribunals made good faith efforts to take seriously the state's 'right to regulate'"); Suzanne A. Spears, The Quest for Policy Space in a New Generation of International Investment Agreements, 13 J. InT'L ECON. L. 1037, 1071 (2010) (arguing that tribunals are increasingly engaged in a "balancing process" and are "called upon to make value judgments").

59 See, e.g., El Paso Energy Int'l Co. v. Argentine Republic, ICSID Case No. ARB/03/15, Decision on Jurisdiction, para. 70 (Apr. 27, 2006) [hereinafter El Paso v. Argentina] ("[A] balanced interpretation is needed, taking into account both State sovereignty and the State's responsibility to create an adapted and evolutionary framework for the development of economic activities, and the necessity to protect foreign investment and its continuing flow."); Total S.A. v. Argentine Republic, ICSID Case No. ARB/04/1, Decision on Liability, paras. 114-34, 115 (Dec. 27, 2010) (States "do not thereby relinquish their regulatory powers nor limit their responsibility to amend their legislation in order to adapt it to change and the emerging needs and requests of their people.").

${ }^{60}$ See, e.g., Waste Management v. Mexico, ICSID Case No. ARB(AF)/00/3, Award, para. 110 (Apr. 30, 2004); Chemtura Corporation v. Government of Canada, Award, paras. 123,134-38 (UNCITRAL Aug. 2, 2010) (noting Canada's "margin of appreciation"); Saluka v. Czech Republic, Partial Award, para. 306 (UNCITRAL Mar. 17, 2006); Continental Casualty Co. v. Argentine Republic, ICSID Case No. ARB/03/9, Award, paras. 189-258, (Sept. 5, 2008) (looking to WTO case law interpreting Article XX of the General Agreement on Tariffs and Trade (GATT) to balance rights and obligations of states and investors).

${ }^{61}$ See UNCTAD, Taking Stock of IIA Reform, IIA ISSUES NOTE \#1, at 9 (Mar. 2016), at http://investmentpolicyhub.unctad.org/Publications/Details/142 (58\% of BITs negotiated between 2012-2014 contain explicit public policy exceptions).

${ }^{62}$ CETA, supra note 41 at pmbl.; 2012 U.S. Model Bilateral Investment Treaty, pmbl., available at http:// www. ustr.gov/sites/default/files/BIT\%20text\%20for\%20ACIEP\%20Meeting.pdf [hereinafter 2012 U.S. Model BIT].

${ }^{63}$ See, e.g., Frank J. Garcia, Lindita Ciko, Apurv Gaurav \& Kirrin Hough, Reforming the International Investment Regime: Lessons from International Trade Law, 18 J. INT'L ECON. L. 861 (2015).
} 
obligations on investors. ${ }^{64}$ Yet even if BITs are not so revised, broader interests are still encompassed within the state's right to regulate and balance social welfare goals.

In our view, focusing on fairness only with regard to foreign investors builds from a number of flawed assumptions and can create a structural tilt against state regulation and the interests of other stakeholders represented by the state. First, a one-sided focus is based on assumptions that can overstate the relative position of the state in relation to investors, which are often large powerful corporations from comparatively rich nations that have many options to protect themselves. Rather than being simply law-abiding, risk-taking victims of excessive, opportunistic governments, investors may have "unclean hands" and their actions can damage the environment, contribute to the violation of human rights, and raise other social concerns.

Second, a one-sided focus on fairness obscures the fact that foreign investors may be in a much stronger position than other stakeholders in relation to the host state through their ability to lobby, bargain contractually, obtain insurance, and harness home state diplomacy. In practice, foreign investors may procure investments under less than transparent conditions to the prejudice of other stakeholders within the state. While it is possible that some governments have the institutional capacity to perform a proper balancing of stakeholder interests, the threat of using ISDS can further advantage well-resourced foreign investors, creating a structural tilt against state regulation that is responsive to the concerns of affected citizens.

Third, a one-sided view presumes domestic courts cannot be trusted. Yet, if this is the case, then domestic stakeholders can be prejudiced as well, but they have no access to a specialized forum to sue foreign investors. An asymmetric focus on fairness in the definition and interpretation of foreign investment law constrains host governments' ability to hold powerful, corporate actors accountable in situations where the alternative of relying on citizen suits before domestic courts is limited or non-existent. Moreover, a traditional ISDS model of substitution could inhibit the development of independent, national adjudicatory processes to fairly assess and balance the different interests at stake. ${ }^{65}$

\section{B. Efficiency}

A second goal of ISDS is to promote resource allocation efficiency through reducing the state's cost of capital and thus increasing national welfare and supporting economic development. The World Bank stressed this goal in creating ICSID and supporting the ensuing ISDS system. In the words of one of the delegates participating in the negotiation of the ICSID Convention: "economic development could not be achieved without capital and . . .

64 See Howard Mann, Konrad von Moltke, Aaron Cosbey \& Luke Eric Peterson, IISD Model International Agreement on Investment for Sustainable Development, Int'l Inst. for Sustainable Development (2006), available at https://www.iisd.org/pdf/2005/investment_model_int_handbook.pdf (explaining reasons to incorporate investor obligations into investment treaties). For a view that BITs already demand some duties to investors, see Bear Creek Mining Corporation v. Republic of Peru, ICSID Case No. ARB/14/21, Partial Dissenting Opinion of Professor Philippe Sands QC (Nov. 30, 2017) (suggesting that the company had an obligation of obtain "social license"). For new BITs including obligations of investors, see Reciprocal Investment Promotion and Protection Agreement Between the Government of the Kingdom of Morocco and the Government of the Federal Republic of Nigeria, Art. 18 (Dec. 3, 2016), available at http:// investmentpolicyhub.unctad.org/Download/TreatyFile/5409 (establishing that investors must uphold the human rights and act in accordance with core labor standards).

${ }^{65}$ See infra section IV(E) (on substitution mechanisms). 
developing countries would not obtain capital unless they provided adequate [legal] guarantees." 66 Law-and-economics scholars highlight this goal. As Alan Sykes writes, "A credible promise of monetary compensation to investors, by contrast, in an amount set by neutral arbitrators, goes much further to reduce investment risk and to achieve the developing countries' goal of lowering the foreign cost of capital." 67

For a rational foreign investor, its choice to invest is a function of the margin of profit needed in light of the risk of investing. The investor's decision is a question of opportunity costs; the greater the risk, the more profit it will require if it is to invest in a location. The cost of capital for investors implicates a state's cost of capital directly and indirectly. States depend on investment, whether public or private, and whether foreign or domestic. Capital inflows into states can take different forms - through loans, bonds, and foreign direct investment. Directly, higher investment risk increases the state's borrowing costs because lenders and bond holders demand higher interest rates. Indirectly, higher risk premiums for foreign investors correlate with higher borrowing costs for states. ${ }^{68}$ Overall, the risks associated with investing in a state affect the state's cost of capital for investment and thus resource allocation efficiency.

From the perspective of efficiency, the titles and preambles of many BITs reflect the goal of efficiency in terms of promoting private investment. ${ }^{69}$ Accordingly, some investment tribunals have focused on investment promotion in interpreting BIT provisions. ${ }^{70}$ In doing so, they can develop jurisprudential standards that appear to create a bias against any new regulation that may prejudice an investor. The tribunal in Tecmed $v$. Mexico, for example, maintained that the investor must "know beforehand any and all rules and regulation that will govern its investments, as well as the goals of the relevant policies and administrative practices or directives." 71 This controversial and expansive phrasing of the standard suggests that regulation should be frozen and not developed in light of experience and democratic choice.

Yet, the dominant trend of investment tribunals is to balance investor protection with a state's right to regulate when deciding on investment claims, such as claims regarding alleged

${ }^{66}$ A. Broches, Gen. Couns., Note Transmitted To The Executive Directors: Settlement Of Disputes Between Government and Private Parties (1961), reprinted in Int'l Ctr. For Settlement Of Investment Disp., 2 The History Of The Sid Convention: Part 1, at 244 (1968). See also Report of the Executive Directors, supra note 18, at para. 9 (ICSID was "designed . . . [as] a major step toward promoting an atmosphere of mutual confidence and thus stimulating a larger flow of private international investment into territories, which is the primary purpose of the Convention.").

${ }^{67}$ Alan O. Sykes, Public Versus Private Enforcement of International Economic Law: Standing and Remedy, 34 J. LeGal STUd. 631, 643 (2005).

${ }^{68}$ See Jeswald Salacuse, Of Handcuffs and Signals: Investment Treaties and Capital Flows to Developing Countries, 58 HarV. INT'L L.J. 127 (2017).

${ }^{69}$ Id., at 130-31 (citing BIT preambles and titles). See, e.g., 2008 German Model Treaty Concerning the Encouragement and Reciprocal Protection of Investments, at pmbl., available at http://www.italaw.com/sites/ default/files/archive/ita1025.pdf ("recognizing that the encouragement and contractual protection of such investments are apt to stimulate private business initiative and to increase the prosperity of both nations").

70 See, e.g., SGS Société Générale de Surveillance S.A. v. Republic of the Phil., ICSID Case No. ARB/02/6, Decision on Jurisdiction, para. 116 (Jan. 29, 2004), 8 ICSID REP. 518 (2005) (the Tribunal found it "legitimate to resolve uncertainties in its interpretation so as to favour the protection of covered investments" because BITs intend to "create and maintain favourable conditions for investments"); Occidental Exploration \& Prod. Co. v. Ecuador, Final Award, paras. 173, 183 (London Ct. Int'l Arb. July 1, 2004), available at https://www.italaw.com/sites/default/files/case-documents/ita0571.pdf (" $\mathrm{t}]$ he stability of the legal and business framework is thus an essential element of fair and equitable treatment").

${ }^{71}$ Técnicas Medioambientales Tecmed, S.A. v. Mexico, ICSID No. ARB(AF)/00/2, para. 154 (May 29, 2003), 43 ILM 133 (2004) [hereinafter Tecmed Award]. 
unfair treatment or indirect expropriation. This approach implicitly conceptualizes resource allocation efficiency from a broader social welfare perspective. ${ }^{72}$ That is, from a law-and-economics perspective, resource allocation efficiency involves the optimality of investment protection, and not investment promotion per se. Otherwise, ISDS will have an anti-regulatory bent since the best way to attract investment would be to limit government regulation. Absolute investment protection is not optimal, and thus not efficient, because it precludes the balancing of other social welfare goals. Indeed, Anthea Roberts rightly points out that jurisprudence that focuses solely on investor protection could trigger state exit from the investment regime, "undermining investor protection and the promotion of efficient investments in the long term." 73

Whether ISDS actually catalyzes investment is forcefully debated, as is the broader question whether increased foreign investment is even desirable as a development strategy. ${ }^{74}$ As Robert Howse writes, the argument that BITs support development through incentivizing foreign investment is based on three premises: (1) that additional investment boosts economic growth and development; (2) that treaty protection will incentivize additional investment; and (3) that treaty protection is cost-effective compared to other state incentives for foreign investment. ${ }^{75}$ All of these premises are contested, both empirically and in terms of economic theory. $^{76}$

The goal of resource allocation efficiency is an important one affecting aggregate national welfare and the prospects of economic growth and development. Yet, from a law-and-economics perspective, the goal of resource allocation efficiency should be framed in terms of optimal investment to advance social welfare, not investment protection per se.

\section{Peace}

A third normative goal of investment dispute settlement is to reduce interstate conflict and thus support peaceful and cooperative international relations. ${ }^{77}$ From this perspective, the

${ }^{72}$ See supra notes 70, 71. On the logic espoused in these cases; see, e.g., Jan Kleinheisterkamp, Investment Treaty Law and the Fear for Sovereignty: Transnational Challenges and Solutions, 78 Modern L. REV. 793, 811 (2015) ("the logic that investment should be protected, not for the sake of individual economic interests but for the purpose of contributing to enhancing social welfare").

${ }^{73}$ Anthea Roberts, Triangular Treaties: The Extent and Limits of Investment Treaty Rights, 56 HaRV. INT'L L.J. 353, 380 (2015).

${ }^{74}$ For a literature review, see Christian Bellak, How Bilateral Investment Treaties Impact on Foreign Direct Investment: A Meta-Analysis of Public Policy (2013), available at http://www2.gre.ac.uk/_data/assets/pdf_file/ 0006/822705/Christian-Bellak-How-BilateralInvestment-Treaties-Impact-on-Foreign-Direct-Investment-AMeta-analysis-of-Public-Policy.pdf ("In a nutshell, the positive impact of BITs on [foreign direct investment (FDI)] has not been confirmed empirically.").

75 Robert Howse, International Investment Law and Arbitration: A Conceptual Framework, in INTERNATIONAL LAW And Litigation 14 (Helene Ruiz-Fabri, ed., forthcoming), available at https://www.iilj.org/wp-content/ uploads/2017/04/Howse_IILJ_2017_1-MegaReg.pdf.

${ }^{76} \mathrm{Id}$. Foreign investment law differs from trade law in that it is not grounded in a widely accepted economic theory, such as the theory of comparative advantage for trade. See Jagdish Bhagwati, The Capital Myth: The Difference Between Trade in Widgets and Dollars, For. AfF., May-June 1998, at 7 (distinguishing the case for free trade and for liberal capital flows); see also Thomas Piketty, Le Capital aU XXI Siecle 120-21 (2013) (dismissing the idea that countries that have seen rapid growth and development especially in Asia received massive FDI).

77 See 2 Convention on the Settlement of Investment Disputes Between States and Nationals of Other States: Documents Concerning the Origin and the Formulation of the Convention, pt. 1, at 303 (1968) (explaining that the ICSID Convention would "serve ... the cause of international co-operation generally" and that the Convention 
adjudication of disputes involving foreign investors helps ensure that investment disputes are resolved by law instead of force or other forms of coercion. Otherwise, investment disputes could trigger costly diplomatic confrontations between the host state and the investor's home state that could escalate and possibly undermine cooperation in other areas.

This goal was central to the World Bank's promotion of the ICSID regime. Ibrahim Shihata stressed the goal—perhaps opportunistically_at a time when the volume of foreign direct investment in developing countries was declining as a consequence of debt crises. ${ }^{78}$ According to Shihata, ISDS was superior because it effectively encourages investment "without inviting the abuses of diplomatic protection" of the past. ${ }^{79}$ This framing particularly resonated among Latin American countries that had suffered reprisals by the United States and European powers in the form of "gunboat diplomacy" ${ }^{0}$ to protect their nationals-actions that generated resistance among Latin American nations to join a system for the international adjudication of investment disputes. ${ }^{81}$

Because the home states of investors historically used coercive methods to resolve investment disputes, some scholars defend ISDS by recalling the past. For example, Judge Schwebel stresses that "the displacement of gunboat diplomacy by international arbitration is a very real achievement." 82 Professor Andreas Lowenfeld, a U.S. negotiator of the ICSID Convention, writes in a NAFTA case that "the essential feature of investor-state arbitration, as it has developed since the ICSID Convention of $1965, \ldots$ is that controversies between foreign investors and host states are insulated from political and diplomatic relations between states." 83

This goal has a long pedigree and links with what is arguably the foremost goal of public international law: to ensure international peace. ${ }^{84}$ Assessing whether this historical depiction overstates the past use of coercive methods or, rather, understates the coercive methods used today, is beyond this Article's scope. We nonetheless note that self-help through the use of force to recover debts is now prohibited under international law, so that arguments regarding

was better than the existing situation of diplomatic protection "which would transform the controversy into a dispute between States"). For a discussion on different understandings of the depoliticization goal, see Roberts, Triangular Treaties, supra note 73, at 388-95.

78 ICSID, ANNUAL RePORT, at 6 (1984) (statement of Ibrahim Shihata arguing that "in an era in which it has become increasingly difficult for a developing country to obtain official development assistance and in which foreign private investment has in recent years diminished markedly, ICSID membership cannot be but a positive element in a developing country's policies").

${ }^{79}$ Ibrahim F. I. Shihata, Towards a Greater Depoliticization of Investment Disputes: The Roles of ICSID and MIGA, 1 ICSID ReV.-For. InV. L.J. 1, 25 (1986).

${ }^{80}$ Sir James Cable, Gunboat Diplomacy 1919-1979: Political Applications of Limited Naval Force 39 (1981).

${ }^{81}$ In 1964, at the Annual Meeting of the Board of Governors of the World Bank in Tokyo, Latin-American countries voted together against the ICSID Convention. For a detailed discussion the negative attitude toward the Convention in Latin America, see Paul C. Szasz, The Investment Disputes Convention and Latin America, 11 VA. J. INT'L L. 256 (1971).

${ }^{82}$ Stephen M. Schwebel, Keynote Address: In Defence of Bilateral Investment Treaties, at 2, available at http:// www.arbitration-icca.org/media/2/14169776244680/schwebel_in_defence_of_bits.pdf.

${ }^{83}$ Corn Products Int'l, Inc. v. Mexico, ICSID Case No. ARB(AF)/04/01, Decision on Responsibility, Sep. Op. Arbitrator Lowenfeld, para. 1 (Jan. 15, 2008).

${ }^{84}$ See generally, RATNER, supra note 6; see also, Ingrid Wuerth, International Law in the Post-Human Rights Era, 96 Tex. L. ReV. 279 (2018). 
the goal of peace arise in a very different context. ${ }^{85}$ In part because of this change, many question the continued usefulness of discussing "depoliticization" in the contemporary context. Martins Paparinskis, for example, contends that it has weak empirical foundations and "has no self-evident use for conceptualizing and resolving modern challenges." ${ }^{86}$ Even with ISDS, he argues, the dispute remains just as politically sensitive. ${ }^{87}$

We add to the debate that the conventional conception of ISDS in terms of depoliticization, once more, has had a rather one-sided, pro-investor focus-it promotes ISDS to advance this end. We contend that the goal of international cooperation between states is indeed an important one, but that it should be viewed equally in terms of reducing constraints on states' ability to adapt regulation to changing contexts in light of experience and new information, including in relation to global and transnational initiatives - think, for example, of the policies behind the "tobacco carve-out" from using ISDS under the Trans-Pacific Partnership Agreement. ${ }^{88}$

Accordingly, we focus on the relative impact of institutional design on the furtherance of the goal of international cooperation and peace. Although international disputes can become politicized under any system, the level of politicization can vary in light of institutional design. In international trade law, for example, the U.S. administration currently threatens to undermine the dispute settlement system of the World Trade Organization (WTO) by blocking the appointment of members to the WTO Appellate Body. ${ }^{89}$ Commentators worry about the long-term consequences for trade relations if this dispute settlement system erodes. For the investment law world, this development raises concern if ISDS were replaced by a court built on the WTO Appellate Body model. The goals of cooperative and peaceful interstate relations, in other words, continue to raise issues of institutional choice.

\section{Reframing the Goals: Protection of the Rule of Law}

We contend that the three conventional goals of investment protection reflected in ISDS_fairness, efficiency, and peace_-are linked both analytically and consequentially to a broader principle_-accountability under the rule of law. In the words of ICJ Judge James Crawford, one of the main roles "of international law is to reinforce, and on occasions

${ }^{85}$ See UN Charter Art. 2, para. 4 ("All Members shall refrain in their international relations from the threat or use of force against the territorial integrity or political independence of any state, or in any other manner inconsistent with the Purposes of the United Nations.").

${ }^{86}$ See Martins Paparinskis, Limits of Depoliticisation in Contemporary Investor-State Arbitration, in 3 SELECT Proceedings of the European Society of International Law 271-82 (James Crawford ed., 2010) (discussing the concept of diplomatic protection and depoliticization).

${ }^{87}$ Id., at 273-75. See also Geoffrey Gertz, Srividya Jandhyala \& Lauge N. Skovgaard Poulsen, Legalization, Diplomacy, and Development: Do Investment Treaties De-politicize Investment Disputes?, 107 WorLd Dev. 239, 240 (2018) (noting ongoing pressure on top developing country offices to resolve disputes); JONATHAN Bonnitcha, Lauge N. Skovgaard Poulsen \& Michael Waibel, The Political Economy of the Investment Treaty Regime, at chs. 7-8 (2017).

88 The Trans-Pacific Partnership Agreement permitted treaty parties to "block corporations from using the [ISDS] mechanism to receive compensation for commercial damages resulting from tobacco control measures"-an example being those promoted transnationally by the World Health Organization. See Sergio Puig \& Gregory Shaffer, A Breakthrough with the TPP: The Tobacco Carve-Out, 16 Yale J. Health Pol'y, L. \& ETHICS (2016).

${ }^{89}$ Jennifer A. Hillman, Independence at the Top of the Triangle: Best Resolution of the Judicial Trilemma?, 111 AJIL Unbound 364-68 (2017); Jeffrey L. Dunoff \& Mark A. Pollack, The Judicial Trilemma, 111 AJIL 225, 22526 (2017). 
to institute, the rule of law internally." 90 In our view, the rule of law provides the guiding principle for international investment law. The concept resonates with traditional justifications for investment law, such as the obligation not to "deny justice," 91 contemporary arbitral jurisprudence regarding the "minimum standard of treatment" and "fair and equitable treatment," 92 and the preamble and other provisions of treaties such as CETA and those based on the 2012 U.S. model BIT. ${ }^{93}$

The meaning of the "rule of law" is, however, contested. ${ }^{94}$ Many legal philosophers focus on abstract formal conceptions of the rule of law, such as the law's generality, equality of application, and certainty. Lon Fuller notably advanced eight elements that constitute conditions for the rule of law-law should be "general, publicized, prospective, clear, non-contradictory, compliable, consistently applied, and reasonably stable." 95 Joseph Raz specified similar principles and divided them into two groups, the first focused on formal standards that provide certainty and predictability to guide action, and the second focused on legal machinery to make the first effective. ${ }^{96}$ These formal concepts of the rule of law highlight the coordinative function of norms by providing a framework against which individuals and organizations might orient action, interact, and plan. ${ }^{97}$

${ }^{90}$ James Crawford, International Law and the Rule of Law, 24 AdELAIDE L. Rev. 3, 8 (2003).

${ }^{91}$ See, e.g., Edwin M. Borchard, The "Minimum Standard" of the Treatment of Aliens, 38 MicH. L. REv. 445, 460 (1939-1940) (stating "[f]air courts, readily open to aliens, administering justice honestly, impartially, without bias or political control, seem essentials of international due process"); Case Concerning Elettronica Sicula S.p.A. (ELSI) (U.S. v. Italy), 1989 ICJ Rep. 15, reprinted in 28 ILM 1109, at para. 128 (citing Asylum Case (Colom. v. Peru), 1950 ICJ Rep. 266, 284) (a case based on an FCN treaty: "[a]rbitrariness is not so much something opposed to a rule of law, as something opposed to the rule of law. . . It is a wilful disregard of due process of law, an act which shocks, or at least surprises, a sense of juridical propriety"). See also Noble Ventures, Inc. v. Rom., ICSID Case No. ARB/01/11, Award, para. 178 (Oct. 12, 2005), available at http://tinyurl.com/4k8pr35 (finding against the complainant because: "Such proceedings are provided for in all legal systems and for much the same reasons. One therefore can not say that they were 'opposed to the rule of law.' . . . Arbitrariness is therefore excluded.”); Plama Consortium Ltd. v. Republic of Bulg., ICSID Case No. ARB/03/24, Award, para. 269 (Aug. 27, 2008), available at http://tinyurl.com/3duq8wh.

${ }^{92}$ See, e.g., Waste Management, supra note 60, at para. 98 (the minimum standard of treatment is "infringed by conduct attributable to the State and harmful to the claimant if the conduct is arbitrary, grossly unfair, unjust or idiosyncratic, is discriminatory and exposes the claimant to sectional or racial prejudice, or involves a lack of due process leading to an outcome which offends judicial propriety-as might be the case with a manifest failure of natural justice in judicial proceedings or a complete lack of transparency and candor in an administrative process"). See also Alain Pellet, Police Power and the State's Right to Regulate, in Building InTERnational Investment Law: The First 50 Years of ICSID (Meg Kinnear, Geraldine Fischer, Jara Minguez Almeida, Luisa Fernanda Torres \& Mairée Uran Bidegain eds., 2016).

93 See, e.g., CETA, supra note 41, at pmbl. ("[Recognizing] the importance of . . the rule of law for the development of international trade and economic cooperation."). Newer versions of BITs provide that "ffair and equitable treatment' includes the obligation not to deny justice in criminal, civil, or administrative adjudicatory proceedings in accordance with the principle of due process embodied in the principal legal systems of the world." See 2012 U.S. Model BIT, supra note 62, Art. 5(2)(a).

${ }^{94}$ Jeremy Waldron, Is the Rule of Law an Essentially Contested Concept (in Florida)?, 21 L. \& PHIL. 137, 138-44 (2002); Judith N. Shklar, Political Theory and The Rule of Law, in The Rule Of Law: Ideal Or IdeOlogy 1 (Allan C. Hutchinson \& Patrick Monahan eds., 1987).

95 See Charles Sampford, Reconceiving the Rule of Law for a Globalizing World, in Globalization and the Rule OF LAW 9, 14 (Spencer Zifcak ed., 2005). Sampford builds from Fuller's list of eight ways in which a legal system can fail. See Lon L. Fuller, The Morality Of Law (rev. ed. 1969). Fuller defends, in his words, a "procedural version of natural law." Id. at 96-97.

96 See Joseph Raz, The Authority of Law: Essays on Law and Morality 214-19 (1979) (listing eight principles).

97 Jeremy Waldron, The Concept and the Rule of Law, 43 GA. L. REv. 1, 48 (2008) ("Law in the first sense requires the existence of certain general norms that serve as a basis of orientation for people's behavior, as well as a basis for decision by the courts."). 
The rule of law becomes more contested when it includes substantive norms and goals, representing political choices, such as a democratic form of government, participation, deliberation, and individual rights. Leading philosophers and social theorists, such as Ronald Dworkin, Jeremy Waldron, Jurgen Habermas, and Philip Selznick, advance different substantive conceptions to attend to broader values realized through law. ${ }^{98}$ In different ways, United Nations reports on the rule of law incorporate substantive conceptions, ${ }^{99}$ as do reports of the Bretton Woods institutions supporting market-oriented development policies. ${ }^{100}$

The rule of law, in our view, is best conceptualized from a socio-legal perspective that focuses on goals and practices. The goal of the rule of law is to create restraints on government in order to provide security and predictability so that individuals and firms can plan their pursuits and do so without fear. ${ }^{101}$ Its basic conception is opposition to the arbitrary exercise of power. Ultimately, for the rule of law to become effective, it must be institutionalized as part of a culture of appropriate conduct. ${ }^{102}$ From a socio-legal perspective, the rule of law provides restraints on arbitrary state behavior, backed by norms that enable people to reasonably know what is required of them, combined with the institutionalization of these norms so that they "count as a source of restraint and a normative resource" that may be used in practice. ${ }^{103}$ Applied to investment law, the rule of law provides foreign investors with the security and predictability that state commitments to them will be upheld. It creates, in the words of investment tribunals, "legitimate expectations" on the part of investors, subject to the state's "right to regulate" to advance social welfare. ${ }^{104}$ To the extent one views the rule of law as also involving processes of participation and deliberation of the governed regarding the

98 See Ronald Dworkin, A Matter of Principle 259 (1985) (proposing the ideal of rule as a public conception of individual rights); Waldron, supra note 97, at 58-59 (concept should emphasize "the procedural and argumentative aspects of legal practice"); JÜrgen Habermas, BetweEn Facts and Norms: Contributions To A Discourse Theory Of LaW AND Democracy 453 (William Rehg trans., 1996) (legitimacy as "procedural rationality"); P. Selznick with P. Nonet \& H.M. Vollmer, Law, Society and Industrial Justice 253 (1969) ("Procedure cannot be 'due' if it does not conform to the canons of rational discourse . . . .").

99 See, e.g., UN Secretary-General, The Rule of Law and Transitional Justice in Conflict and Post-Conflict Societies, para. 6, UN Doc. S/2004/616 (Aug. 23, 2004) (rule of law as a "principle of governance in which all persons, institutions, and entities, public and private, including the State itself, are accountable to laws that are publicly promulgated, equally enforced and independently adjudicated, and which are consistent with international human rights norms and standards").

100 See Erik Jensen, The Rule of Law and Judicial Reform: The Political Economy of Diverse Institutional Patterns and Reformers' Responses, in Beyond Common Knowledge: EMPIRICAl Approaches to the Rule of LaW 336 (Eric Jensen \& Thomas Heller eds., 2003); Kathryn Hendley, The Rule of Law and Economic Development in a Global Era, in The Blackwell Companion to LaW and Society 605 (Austin Sarat ed., 2004); Patrick McAuslan, Law, Governance and the Development of the Market: Practical Problems and Possible Solutions, in GoOD GOVERNMENT and Law: Legal and Institutional Reform in Developing Countries 25, 42 (Julio Faundez ed., 1997) ("[In] World Bank publications . . . the rule of law ... is being redefined to emphasize its role in facilitating the enforcement of private contracts so that law reform to advance the rule of law is the same as law reform to advance the market economy.”).

${ }^{101}$ Martin Krygier, The Rule of Law: Legality, Teleology, Sociology, in Relocating The Rule Of Law 45, 60 (Gianluigi Palombella \& Neil Walker eds., 2009).

${ }^{102}$ Id., at 58-60. Tamanaha thus defines the rule of law to mean that "government officials and citizens are bound by and abide by the law." Brian Tamanaha, The History and Elements of the Rule of Law, SiNGAPORE J. LEGAL STUD. 232, 233 (2012).

${ }^{103}$ Krygier supra note 101, at 60. See also Brian Tamanaha, On the Rule of Law: History, Politics, Theory 141 (2004); Philippe Nonet \& Philip Selznick, Toward Responsive Law: Law and Society in Transition 53 (2017) ("The rule of law is better understood as a distinctive institutional system than as an abstract ideal.").

${ }^{104}$ Krygier, supra note 101 , at 58. 
institutions that govern them, then that conception has implications for investment dispute settlement as well, highlighting the role of domestic institutions that are closer to the governed, with international mechanisms serving as complements to them, as addressed below. ${ }^{105}$

We contend that the socio-legal framing of the rule of law is linked with our conceptualization of the three goals of investment law discussed above both analytically and conceptually. ${ }^{106}$ First, the rule of law principle can be viewed analytically as incorporating the concept of procedural fairness in terms of law's inner morality (in Fuller's sense when viewed in terms of actual practice). ${ }^{107}$ John Rawls, for example, defines the rule of law as "the regular, impartial, and in this sense fair, administration of law." ${ }^{108}$ Notably, the concept of fairness under the rule of law is symmetric for all stakeholders, and thus does not privilege foreign investors; for other stakeholders in the investment process, for example, the rule of law helps ensure that government officials do not engage in corrupt transactions or otherwise favor foreign investors over other interests. ${ }^{109}$ Viewed consequentially, there is good reason to believe that the rule of law contributes to fairness, as the Marxist historian E.P. Thompson stressed in the conclusion of his magisterial study of English enclosure laws. ${ }^{110}$

Second, the rule of law principle can be viewed analytically as incorporating the concept of resource allocation efficiency when law is viewed in terms of "planning" that helps to coordinate behavior-as in Scott Shapiro's work. ${ }^{111}$ Those who stress efficiency as a goal, however, are generally consequentialists. From a consequentialist perspective, the rule of law contributes to resource allocation efficiency and thus economic development by increasing transparency, preventing corruption, and reducing political risk. ${ }^{112}$ Once again, it does not do so from a one-sided focus on investment promotion, but rather from a broader social welfare perspective. Indeed, some empirical evidence shows that, in most contexts, decreased risk in a country's political and legal system-including indicators for law and order-correlates with higher levels of investment. ${ }^{113}$

Third, the rule of law links analytically with the concept of peace by stressing the use of law to resolve conflicts in lieu of power. To turn to a consequentialist perspective, the rule of law

105 See infra section IV(F) [on international mechanisms as complements].

106 See also Howse, supra note 75, at 34 (noting three rule of law rationales that can be read as linked to efficiency (to address the hold-out problem), fairness (to improve the rule of law), and peace (depoliticization).

107 See Fuller, supra note 95.

108 RaWls, Theory OF Justice, supra note 49, at 235.

109 See Garcia, Ciko, Gaurav \& Hough, supra note 63, at 871 (“[E]ven if ISDS strengthens the rule of law for one class of stakeholders (investors), this is no substitute for the larger systemic evaluation of ISDS in terms of the rule of law for all stakeholders, not just favored investors."). See, e.g., Spentex Netherlands, B.V. v. Republic of Uzbekistan, ICSID Case No. ARB/13/26, Award (Dec. 27, 2016) (The tribunal ruled that one purpose of the investment system is to promote the rule of law, which precluded offering protection to investor that engaged in unlawful activities.). For an example of the treatment of corruption in an ISDS case, see World Duty Free Co. v. Republic of Kenya, ICSID Case No. ARB/00/7, para. 120 (Oct. 4, 2006), 46 ILM 339 (2007).

${ }^{110}$ E.P. Thompson, Of Whigs and Hunters: The Origin of the Black ACt 258-69 (1975).

111 See, e.g., SCOTt Shapiro, Legality (2011) (providing “a planning theory of law" that conceptualizes "legal systems" as "institutions of social planning").

112 See, e.g., Douglas North, Institutions, Institutional Change, and Economic Performance (1990).

113 Robert J. Barro, Determinants of Economic Growth: A Cross-Country Empirical Study (1996); Kyeonghi Baek \& Xingwan Qian, An Analysis on Political Risks and the Flow of Foreign Direct Investment in Developing and Industrialized Economies, 6 Econ. Mgmt. \& Fin. Markets 60, 64 (2011). Cf. Jason Webb Yackee, Political Risk and International Investment Law, 24 DuKe J. Comp. \& INT'L L. 477 (2014) (noting the limits of political risk theories). 
can reduce international conflict that otherwise arises when state authorities seize foreign investor property or otherwise deny foreign investors justice. Democratic peace theory provides evidence that democracies grounded in the rule of law are less likely to go to war against each other. ${ }^{114}$ Once more, the rule of law principle does not have a one-sided focus on investors-i.e., focusing on a private right of standing to depoliticize investment disputes-but rather one that encompasses all stakeholders in the investment process.

From a socio-legal perspective, the ultimate challenge for the rule of law is its implementation in practice, which will be mediated by social institutions and legal culture. Because law is frequently ambiguous, often involving the interplay of standards, rules, and exceptions, the application of the rule of law will always be contested. ${ }^{115}$ No legal process is "discretion-free" because law's meaning is mediated through the operation of institutions and interactions involving people. Thus, any meaningful understanding of the rule of law must be based on cultures of practice embedded in institutions.

One of the disconnects in the field of ISDS is that proponents focus on the need for investment arbitration because of challenges with the domestic rule of law, while opponents focus on the failure of ISDS to adhere to rule-of-law standards. Yet, both of these mechanisms are subject to severe imperfections. Thus, any meaningful choice between them from a rule-oflaw perspective must engage with a comparison of their trade-offs, along with those of other institutional alternatives. This calls for comparative institutional analysis.

\section{The Framework: Comparative Institutional Analysis}

However one frames the goals of investment law, those goals must be pursued through institutional mechanisms involving interested actors and different decision-making processes. ${ }^{116}$ Thus, goal choice must be complemented by institutional analysis, whatever the goal may be. For institutional analysis, the key question is: compared to what? Neil Komesar powerfully developed comparative institutional analysis and applied it to U.S. domestic law. ${ }^{117}$ Other scholars have applied the framework to European Union law and WTO law, but, to our knowledge, not explicitly to international investment law. ${ }^{118} \mathrm{We}$ do so here.

In critiquing or advocating a particular institutional choice, one should not focus on the defects of a single institution while failing to apply the same rigor to its alternatives. Institutions should rather be assessed from a comparative perspective, one that avoids ideal characterizations in favor of analysis that takes account of real-life institutional pathologies.

\footnotetext{
114 See, e.g., Michael Doyle, Liberal Peace: Selected Essays 4 (2012) (referring to States "founded on such individual rights as equality before the law, free speech and other civil liberty, private property, and elected representation" and notably "freedom from arbitrary authority"). For a precursor, see ImMANUEL KANT, PERPETUAL Peace: A Philosophical Sketch (1795).

${ }_{115}$ See, e.g., Duncan Kennedy, Form and Substance in Private Law Adjudication, 89 Harv. L. Rev. 1685 (1976).

116 See KOMESAR, supra note 2, at 24.

${ }^{117}$ Id. at 2. See also Neil K. Komesar, Law's Limits: The Rule of LaW and the Supply and Demand of Rights (2002).

${ }^{118}$ For E.U. law, see Miguel Maduro, We the Court: The European Court of Justice and the European Economic Constitution (1998); For WTO law, see Gregory Shaffer \& Joel Trachtman, Interpretation and Institutional Choice at the WTO, 52 VA. J. INT'L L. 103 (2011). On investment law, see nonetheless Howse, supra note 75 , at 32, a powerful piece on investment law in a comparative vein, though it does not explicitly engage with this framework.
} 
Just as Ronald Coase labeled economic analyses that compare an existing institution (say the legislative process) with an "ideal" alternative (say the market) as "blackboard economics,"119 much international legal scholarship similarly fails to compare institutional alternatives, especially legal processes, that take account of their real-world complexity.

A more realistic assessment of the possible approaches for resolving investment disputes should take account of three central points: first, that the pursuit of any normative goal is mediated by social decision-making processes; second, that these decision-making processes are biased in different ways because of the dynamics of participation within them; and third, that any meaningful public policy analysis must involve comparative institutional analysis of real-world (rather than ideal) alternatives. The key is to assess institutional alternatives comparatively. To do so, one looks at such factors as numbers, complexity, and per capita stakes that shape the dynamics of participation. One then assesses the implications of these dynamics on different forms of bias in institutional decision-making.

\section{A. Participation: Numbers, Complexity, and Per Capita Stakes}

A focus on participation in institutional decision-making processes should address both the benefits and costs of participation. Understanding the role of numbers, complexity, and per capita stakes is critical for this analysis. Where there are large numbers of affected individuals who have low per capita stakes, serious collective action problems arise. The benefits may be large in aggregate, but they are not large enough for individuals to attend closely to complex issues. Applied to international investment law, this analysis suggests that individuals are unlikely to organize in opposition to expansive investor protections or to ISDS, whether based on an investment contract, a national law, or an international treaty. In contrast, investors have high per capita stakes in investment projects, which creates the incentive for them to assess benefits and costs. Investors thus may deploy significant resources to shape investment law norms and their application. They are, in sum, well-positioned to lobby for investment protection ex ante and to litigate for favorable interpretations and compensation ex post. ${ }^{120}$

The organization of interests in relation to institutional decision-making has ex ante and ex post dimensions - involving dynamics of participation before and after a dispute arises. The investing firm often has much better information regarding environmental and social risks at stake from a prospective investment, but it may not disclose them. After harms become evident, organizing becomes less demanding for affected communities. This dynamic particularly occurs with local decision-making, where numbers are smaller and so it is easier for individuals to overcome collective action problems when harms become salient.

Organized groups—what Komesar calls "catalytic subgroups"-may have interests in common with the local majority and spur their increased participation. These groups can publicize harms and rally residents to oppose investment projects and place pressure on government officials. ${ }^{121}$ Today, the development of social media can assist their mobilization

${ }^{119}$ Ronald Coase, The Firm, The Market and The Law 28 (1988).

${ }^{120}$ One may also see cycles of lawmaking. After the law initially favors some groups (such as foreign investors), other groups organize (such as through non-governmental organizations). Where foreign investors challenge politically important regulation in rich countries, these groups can help mobilize civil society. They thereby can exercise greater influence on reform processes, as has occurred in Europe regarding foreign investment law treaties.

${ }^{121}$ Komesar, supra note 2, at 84. 
efforts. International investment dispute settlement thus has analogues with local government decisions since disputes can pit outsider investors against a local community. This local "majority" may, in turn, not take account of the broader social and development concerns of the province or nation, much less the costs imposed on a foreign investor with high sunk costs. ${ }^{122}$ Seen from this perspective, it is not surprising that a number of ISDS cases involve municipalities denying or cancelling permits to operate locally. ${ }^{123}$

\section{B. Decision-making: Minoritarian and Majoritarian Bias}

Institutional decision-making inevitably involves the push and pull of different forces in light of the dynamics of participation. These forces give rise to different forms of minoritarian and majoritarian bias. ${ }^{124}$ Minoritarian bias appears when well-organized, discrete interests shape policy. In investment law, this could involve a foreign investor colluding with a domestic government official or, alternatively, a domestic business seeking an advantage over a foreign investor. Majoritarian bias, in contrast, appears when the many oppress the few, imposing higher costs on them.

Assessing these different forms of bias requires a benchmark, which we view in terms of weighing the welfare of all stakeholders equally. While some law-and-economics scholars see the benchmark objectively in terms of resource allocation efficiency, an external, objective assessment becomes difficult, if not impossible, when goals are incommensurate, as they invariably are with public policy. Our focus thus centers on participation in social decision-making processes. From a law-and-economics perspective, participation and social welfare are closely related since, as Komesar writes, "participation is the heart of key economics concepts such as transaction costs, externalities and resource allocation efficiency." 125

These different forms of bias in participation in social decision-making processes have distinct dynamics and impacts in the investment law context. For example, minoritarian bias favoring foreign investors may adversely affect domestic stakeholder interests because of adverse environmental and social impacts and other externalities. In contrast, majoritarian bias may adversely affect foreign investors but have different short- and long-term effects on domestic stakeholders. In the short term, domestic politics might favor reneging on a contractual obligation or triggering an expropriation when a country is faced with large budget

\footnotetext{
${ }^{122} \mathrm{Id}$. at 79 ("Land use decisions by small jurisdictions are classic examples of instances in which large numbers with lower per capita impacts [residents of developed parcels] can dominate small numbers with higher per capita stakes [residential developers or owners of undeveloped land].").

123 See, e.g., Metalclad v. Mexico, ICSID Case No. ARB(AF)/97/1, Award (Aug. 30, 2000) (concerning the denial of construction permit and designation of an ecological zone); Tecmed, supra note 71 (concerning a denial of permit for landfill in a rapidly growing municipality); Glamis Gold, Ltd. v. United States, Award, paras. 5-25 (NAFTA Ch. 11 Arb. Trib. June 8, 2009), 48 ILM 1038 (concerning a denial of mining permit in response to pressure from a local indigenous community). For an excellent discussion of regulatory takings cases, see Steven R. Ratner, Regulatory Takings in Institutional Context: Beyond the Fear of Fragmented International Law, 102 AJIL 475 (2008).

${ }^{124}$ Komesar calls this a two-force model of politics. KOMESAR, supra note 2, at 65-89.

125 Neil Komesar, The Essence of Economics: Law, Participation and Institutional Choice (Two Ways), in Alternative Institutional Structures: Evolution and Impact 165, 170 (Sandra S. Batie \& Nicholas Mercuro eds., 2008)
} 
deficits or immediate resource needs. ${ }^{126}$ However, these actions could have long-term adverse effects on a country's ability to attract capital.

Schools of scholarship often reflect particular ideological predispositions and accordingly tend to focus on biases in particular institutions. For example, public choice approaches focus on minoritarian bias in political processes, assessing the power of the few to shape decisionmaking, resulting in discrimination and regulatory capture. ${ }^{127}$ Scholars working in this vein often favor the use of market processes to avoid these biases (think, for instance, of much of the scholarship in international trade law). A comparative institutional analysis reveals, however, that market processes also may be skewed because most affected actors are dormant, disorganized, uninformed, or misled. Indeed, were markets to function effectively, competition for investment capital could discipline governmental decision-makers, obviating the need for international investment law in the first instance.

Rights claims can trigger judicial intervention against regulatory decision-making to protect minoritarian interests against majorities. Such intervention may involve a single investor with high per capita stakes on one side and large groups with low per capita stakes on the other. Where they overcome collective action problems, these groups can press officials to impose high costs on sunk investments through ex post regulations or expansive interpretations of existing ones. Investors may have been in a powerful position in drafting contracts and lobbying for regulations ex ante because of their higher per capita stakes compared to the general public, which faced significant information and organizational costs regarding a proposed project. The project's opponents, however, can become more powerful ex post after the investment was made and its ensuing costs became apparent.

Judicial processes can help correct for majoritarian biases by offering the advantage of evenhandedness and legal reasoning - hallmarks of the rule of law. Yet, courts too are subject to limitations and other biases. Judicial processes are expensive to use on a case-by-case basis, thus favoring parties with financial means and high per capita stakes. Judicial processes may thus favor investors who hire sophisticated lawyers to shape the interpretation of open-ended provisions and create favorable legal doctrines over time. In this way, the "haves" may come out ahead in adjudication. ${ }^{128}$ Judicial processes, moreover, have limited resources to handle the range of social conflicts. In short, they involve high access costs and limits of scale given the mass of decisions affecting investments. Judicial processes, moreover, can be remote from the public so that they may be less able to integrate information and balance competing concerns than political processes. International courts particularly face information costs regarding domestic concerns, potentially giving rise to different forms of bias. ${ }^{129}$

\footnotetext{
126 The two most common ISDS claims are violations of "fair and equitable treatment" (including specific commitments made to investors that creates "justified expectations") and expropriations (particularly indirect expropriations, as in the Argentine cases, but also direct ones, as in the Venezuela cases). See Arbitral Lawmaking, supra note 58.

127 See, e.g., George J. Stigler, The Theory of Economic Regulation, 2 Bell J. EcOn. \& MAN. SCI. 3 (1971); JAMES M. Buchanan and Gordon Tullock, The Calculus of Consent: Logical Foundations of Constitutional DEMOCRACY (1962).

${ }^{128}$ Marc Galanter, Why the 'Haves' Come out Ahead: Speculations on the Limits of Social Change, 9 LaW \& Soc'Y REV. 95 (1974).

${ }^{129}$ On the relationship of mass public and international courts, see Erik Voeten, Public Opinion and the Legitimacy of International Courts, 14 THEORETICAL INQUIRIES L. 411 (2013). For some biases that result from the use of domestic courts in relation to domestic publics, see, e.g., Todd L. Allee \& Paul K. Huth, Legitimizing Dispute Settlement: International Legal Rulings as Domestic Political Cover, 100 Am. Pol. SCI. REv.
} 
Much criticism of ISDS, for example, contends that large multinational corporations, allied with the arbitration bar, bring aggressive claims to chill regulation that would otherwise serve the public interest. ${ }^{130}$ In addition, institutional mechanisms vary in their cost effectiveness in resolving disputes, which needs to be assessed.

Since all institutional processes are imperfect, they are generally distrusted; but they are distrusted in different ways. The creation of investment rights implies distrust of national government, as well as markets. BITs imply a distrust of domestic law. The turn to ISDS implies distrust of domestic courts. The use of balancing tests by ISDS tribunals implies a distrust of political processes and markets. In turn, the proposal for a multilateral investment court system implies distrust of ISDS. This parade of institutional distrust is not surprising, since each institutional alternative is imperfect. For any meaningful policy analysis, however, their imperfections need to be compared and contrasted.

Whatever the goals, and however they are characterized, comparative institutional analysis is required because institutional processes mediate the pursuit of such goals. As Komesar writes, "[i]t is institutional choice that connects goals with their legal and public policy results." ${ }^{131}$ In weighing different institutional alternatives, the issue of participation, shaped by numbers and per capita stakes, is always central. Biases exist in all institutions, but they differ in degree and kind. Only after comparative institutional analysis should choices be made.

\section{Institutional Alternatives and InVestment LaW}

An analysis of institutional alternatives for handling unfair treatment, discrimination, and expropriation of foreign direct investments should include not only the range of plausible adjudicatory options, but also non-adjudicatory mechanisms. We apply comparative institutional analysis to assess six types of such options: (1) market mechanisms; (2) political mechanisms; (3) domestic dispute settlement mechanisms; (4) independent interstate adjudicatory mechanisms; (5) international adjudicatory mechanisms as substitutes for domestic adjudication; and (6) international adjudicatory mechanisms as complements of domestic adjudication. We explain the trade-offs of each of these institutional alternatives in relation to the goals of investment law, on the one hand, and in light of biases of participation in decision-making, on the other.

\section{A. Market Mechanisms}

\section{Reputation, contract, and insurance}

The relative superiority of adjudication in relation to market mechanisms to ensure just treatment of foreign investors is not immediately evident, especially once one takes into

219 (2006). On the relationship of mass publics to courts, see John Ferejohn, Judicializing Politics, Politicizing Law, 65 Law \& Contemp. Probs. 41 (2002).

${ }^{130}$ See, e.g., Tienhaara, Regulatory Chill, supra note 38, at 606 (arguing that regulatory chill may be an important problem "inadequately addressed and often prematurely dismissed by legal scholars"). See also Julian Arato, Corporations as Lawmakers, 56 HARV. INT'L L.J. 229, 231 (2015) (ISDS helps corporations "to create norms of international law_-norms that bear a particular kind of relationship of priority to the state party's domestic legal order."). For a critique of the arbitration bar, see Pia Eberhardt \& Cecilia Olivet, Profiting from Injustice: How Law Firms, Arbitrators and Financiers are Fueling an Investment Arbitration Boom, Corp. Eur. Observatory \& TranSNaT'L. Inst. (2012), available at https://corporateeurope.org/sites/default/files/publications/profitingfrom-injustice.pdf.

${ }^{131}$ KOMESAR, supra note 2, at 5. 
account the economic, political, and social costs of litigation. These costs are particularly salient when companies can deploy the threat of international arbitration under BITs to "chill" regulatory initiatives. In such cases, to borrow from Brian Tamanaha, we risk seeing "the rule of some groups over others by and through the law," more than a "rule of law that furthers the common good." 132 In the discussion that follows, we address the trade-offs of three market mechanisms - reputation, contract, and political risk insurance-in light of the goals of investment law and the different biases of these mechanisms.

The first market mechanism, reputation, is straightforward. Most states prefer to attract investment at a lower cost. Thus, if a state develops a reputation of high risk for foreign direct investment, investors will require a higher rate of return or will simply forego investing in the state. The market for capital investment thus creates pressure on states to treat foreign direct investment fairly. Indeed, states can, and at times do, enact foreign investment legislation through which they commit to use ISDS in limited ways; in this context, state governments are freer to tailor commitments to their view of state needs than when negotiating a BIT. ${ }^{133}$

The market alone, however, may not induce countries to treat investment fairly. State officials may not consider reputational effects, or the countries' approaches toward foreign direct investment may change. Tomz shows that investors respond to the reputation of the government in power, and not of the state itself. ${ }^{134}$ The possibility of significant political change can thus make the assessment of reputation fragile, leading to a short-term focus.

Second, investors can bargain with governments on a case-by-case basis and negotiate investment protections by contract, such as with a state-controlled enterprise. In these contracts, the parties may refer disputes to domestic courts, foreign courts, or international arbitration and specify the applicability of domestic, foreign, or international law. ${ }^{135}$ Brazil, for example, has never adopted a BIT with ISDS, but it is among the world's largest recipients of foreign direct investment-in part because investors are able to obtain protection through contracts that provide for arbitration. ${ }^{136}$ As Howse explains, "[a] contractual solution may

${ }^{132}$ Brian Z. Tamanaha, LaW as a Means to an Ends: Threat to the Rule of LaW 225 (2006) (emphasis in original).

${ }^{133}$ Christoph Schreurer, Investment Arbitration Based on National Legislation, in VÖLKERRECHT UND DIE Dynamik der Menschenrechte, Liber Amicorum Wolfram Karl 527 (Gerhard Hafner, Franz Matscher \& Kirsten Schmalenbach eds., 2012).

${ }^{134}$ Michael Tomz, Reputation And International Cooperation: Sovereign Debt Across Three Centuries 11-22, 39-113 (2007). See also Rachel Brewster, Unpacking the State's Reputation, 50 Harv. InT'L L.J. 231, 258 (2009).

135 Christopher Greenwood, State Contracts in International Law: The Libyan Oil Arbitrations, 53 BRIT. Y.B. INT'L L. 27 (1982). For contractual arbitration clauses to be effective, a body of law is generally needed to enforce the arbitration award, such as the ICSID Convention and the New York Convention on the Recognition and Enforcement of Foreign Arbitral Awards. See Convention on the Recognition and Enforcement of Foreign Arbitral Awards, June 10, 1958, 21 UST 2517, available at http://www.uncitral.org/pdf/english/texts/arbitration/NY-conv/New-York-Convention-E.pdf.

136 See UNCTAD, World Investment Report 2016, Investor Nationality: Policy Challenges (2016), available at http:// unctad.org/en/PublicationsLibrary/wir2016_en.pdf (ranking Brazil third for inward FDI between 1990-2015); Hogan Lovells, Risk and Return: Foreign Direct Investment and the Rule of Law (2015), available at https://www.biicl.org/documents/ 625_d4_fdi_main_report.pdf?showdocument=1 (reporting survey of industry leaders listing Brazil as among the countries where 'rule of law' issues can be avoided with arbitration). 
be superior in many instances as the host state can target the protection to investors that it desires to attract." 137

Existing data shows that resource-intensive sectors that require large up-front capital investments are frequent users of ISDS. ${ }^{138}$ Over half of all ISDS cases relate to oil, gas, and mining ( 25 percent), energy production (17 percent), or water, sanitation, and construction (12 percent) - sectors that require large capital investments. ${ }^{139}$ The irony is that it is precisely in these sectors, comprised of sophisticated multinational companies, where investors are relatively better positioned to resolve the "hold-up" risk through contract (which can provide, inter alia, for international arbitration), instead of relying on broad treaty protections with ISDS. These investors of course prefer the addition of ISDS - which creates a baseline of protection that includes an international remedy from which they can engage in further contracting-but the question is whether ISDS is necessary for them, especially in light of the problems with ISDS discussed below.

Third, because economic actors may be unable to "self-insure" efficiently, including by hedging against risks through diversifying, planning, or contracting, they may turn to the insurance market to reduce non-commercial risk. A market for political risk insurance can protect foreign investors, including against unfair, discriminatory, or expropriatory treatment. ${ }^{140}$ Insurance is often provided by governmental and international bodies (such as the Overseas Private Investment Corporation (OPIC) or the Multilateral Investment Guarantee Agency (MIGA)). ${ }^{141}$ These bodies, in turn, can use political and legal mechanisms to press recalcitrant states to comply with their commitments to investors.

There appears to be a renewed interest in returning to these market mechanisms. In the renegotiations of the NAFTA, for example, USTR Lighthizer contended that U.S. investors should rely on political risk insurance if they are concerned about investment risk. ${ }^{142}$ This assertion has particular resonance for the large investors that bring most ISDS claims and are better positioned to purchase political risk insurance. ${ }^{143}$

\footnotetext{
${ }^{137}$ Howse, supra note 75, at 32. See also Jason Webb Yackee. Do We Really Need BITs? Toward a Return to Contract in International Investment Law, 3 Asian J. WTO \& HEALTH L. \& POL'y 121 (2008) (on the desirability of contractual dispute settlement).

${ }^{138}$ Emilie M. Hafner-Burton, Zachary C. Steinert-Threlkeld \& David G. Victor, Predictability Versus Flexibility: Secrecy in International Investment Arbitration, 68 WORLD POL. 413 (2016). Kobrin, supra note 55.

${ }^{139}$ ICSID, The ICSID Caseload - Statistics, Issue 2017-1, at 12 (Dec. 31, 2017), available at https://icsid.worldbank.org/en/Documents/resources/ICSID\%20Web\%20Stats\%202017-1\%20(English)\%20Final.pdf.

140 See Shihata, supra note 79, at 13-24 (describing the role of Multilateral Investment Guarantee Agency, or MIGA, in providing political risk insurance); Kenneth W. Hansen, Managing Political Risks in Emerging Market Investment, 18 TRANSNAT'L L. 77 (2004).

${ }^{141}$ See Efraim Chalamish \& Robert Howse, Conceptualizing Political Risk Insurance: Toward a Legal and Economic Analysis of the Multilateral Investment Guarantee Agency (MIGA), in The Transnational LaW of Public Contracts (Mathias Audit \& Stephan Scheill eds., 2015).

${ }^{142}$ Donnan, supra note 46. Cf. Taylor St John, The Rise of Investor-State Arbitration: Politics, LaW, AND UNINTENDED CONSEQUENCES 217-20 (2018) (noting that ISDS was promoted initially with the understanding that it would not promote FDI into developing countries at the expense of investments in the United States).

${ }^{143}$ European Commission, Investor-to-State Dispute Settlement: Some Facts and Figures, at 4 (Mar. 12, 2015), available at http://trade.ec.europa.eu/doclib/docs/2015/january/tradoc_153046.pdf (citing OECD figures showing " $48 \%$ of the cases were brought by medium and large enterprises, varying in size from several hundred employees to tens of thousands of employees").
} 


\section{Trade-offs of market mechanisms}

Seen from the perspective of investment law's goals, there are trade-offs to these market approaches. As regards fairness and the rule of law, market mechanisms such as reputation and risk insurance permit an investor to bypass court proceedings, effectively delegating these concerns to the market. ${ }^{144}$ Insurance alone, however, should be less effective than adjudication in deterring host government decisions ex ante because it focuses on replacement dollars paid by a third party based on a past event. ${ }^{145}$ Contracting, in contrast, permits the state and investor to define what is fair, subject to a dispute settlement mechanism to enforce the bargain. However, if most contracts provide for international commercial arbitration or a foreign judicial forum for dispute settlement, then there will be fewer incentives for the state to invest in independent, impartial, quality domestic dispute settlement mechanisms. Moreover, contracts and international commercial arbitration lack transparency, providing less assurance that public law concerns will be fairly addressed. As for the goal of interstate conflict avoidance, it is conventionally understood that international judicial processes are better than market approaches in constraining the investor's home state from getting involved when a conflict escalates. ${ }^{146}$

Market mechanisms are typically touted on efficiency grounds. However, contracting and insurance can be costly (because of bargaining and information costs), especially for smalland medium-sized investors. Given relatively fixed transaction costs, small investors are less likely to invest resources to bargain with governments for protections, including choice-of-law and dispute settlement clauses, to shield them against the risks of mistreatment. Where investors are priced out of or otherwise unable to obtain insurance or negotiate contracts, their investment may be deterred, raising the state's cost of capital. ${ }^{147}$ Alternatively, states interested in reducing their cost of capital may invest in domestic institutions to encourage investment, reduce risk insurance premiums, and facilitate contract enforcement. In practice, therefore, market mechanisms may be sufficient in many cases.

For major cross-cutting events such as civil war or economic crises affecting many or all investments, it arguably is preferable to rely on market mechanisms such as political risk insurance and currency and other forms of hedging, rather than ex post adjudication, so that investors take precautions and price risks accordingly. An example is the collapse of the Argentine peso, which affected large numbers of investments in Argentina, and which arguably was a foreseeable risk over the long term given the history of financial crises in that country. As Anne van Aaken writes regarding one famous ISDS decision,

Although the tribunal held in its decision on jurisdiction that "Bilateral Investment Treaties are not insurance policies against bad business judgments," . . insuring bad

\footnotetext{
${ }^{144}$ Cf. Timothy Sinclair, The New Masters of Capital: American Bond Rating Agencies and the Politics OF CREDITWORTHINESS (2005) (on the pathologies of private governance through credit agencies).

${ }^{145}$ Komesar, supra note 2, at 165-66.

146 Jan Paulsson, Arbitration Without Privity, 10 ICSID ReV.-For. INV. L.J. 232, 256 (1995).

147 Lauge N. Skovgaard Poulsen, The Importance of BITs for Foreign Direct Investment and Political Risk Insurance: Revisiting the Evidence, in Y.B. INT'L INV. L. \& POL'y 2009-2010, at 539, 543 (2010) (“smaller investors may have less bargaining power when negotiating contracts with host governments compared to large multinationals"); Sykes, supra note 67, at 632.
} 
or at least quite imprudent business judgment is exactly the consequence of the CMS tribunal's decision on the merits. ${ }^{148}$

In terms of bias in participation and decision-making, to the extent that contract and insurance are available only for large investors with high per capita stakes, these mechanisms can give rise to minoritarian bias in favor of those actors in relation to smaller investors, be they foreign or domestic. If market mechanisms fail to spur the development of domestic ruleof-law institutions, there will be ongoing risks of majoritarian and minoritarian biases against investors. However, these mechanisms remain important alternatives (or complements), especially for states concerned with diminution of sovereignty from international adjudicatory mechanisms.

\section{B. Political Mechanisms}

\section{Negotiation and mediation}

Conflicts over the treatment of foreign direct investment can also be resolved through political bargaining, thus avoiding the cost of insurance or adjudication. ${ }^{149}$ Mediationnegotiation facilitated by a neutral third party — seems to be increasingly used in international business generally, ${ }^{150}$ and negotiation has been used to address many investment conflicts. ${ }^{151}$ While such negotiations and mediations often occur informally and without much transparency, some countries are promoting more institutionalized alternatives through treaties. For example, MERCOSUR's Protocol on Investment Cooperation and Facilitation provides for direct state-to-state negotiations (Article 24) and mediation (Article 23). ${ }^{152}$ These procedures are based on Brazil's model Agreement on Cooperation and Facilitation of Investments (ACFI), which the Brazilian government has promoted as an alternative to traditional BITs. ${ }^{153}$

\footnotetext{
${ }^{148}$ Anne van Aaken, On the Necessity of Necessity Measures: A Response to Alan O Sykes, 109 AJIL UnBOUND 181, 184 (Dec. 23, 2015) (referring to CMS decision, Gas Transmission Co. v. Argentina, ICSID Case No. ARB/01/08, para. 368 (May 12, 2005), 44 ILM 1205 (2005).

${ }^{149}$ Gertz, Jandhyala \& Poulsen, supra note 87 (noting the ongoing role of diplomacy). See also P.F. Sutherland, The World Bank Convention on the Settlement of Investment Disputes, 28 INT'L \& CoMP. L. Q. 367 (1979) (explaining that the impetus for ICSID included the World Bank's role for informal mediation of disputes with foreign investors).

${ }^{150}$ See, e.g., S.I. Strong, Beyond International Commercial Arbitration?: The Promise of International Commercial Mediation, 42 WASH. U. J. L. \& POL'Y 11 (2014).

${ }^{151}$ For example, Bolivia and Brazil engaged in highly publicized negotiations after an acrimonious dispute over the nationalization of two oil refineries in Bolivia owned by Petrobras, the Brazilian state-controlled enterprise. See Jonathan Wheatley \& Hal Weitzman, Bolivia and Brazil Resolve Oil Disputes, Fin. Times (May 11, 2007).

${ }^{152}$ See Facundo Perez Aznar \& Henrique Choer Moraes, The MERCOSUR Protocol on Investment Cooperation and Facilitation: Regionalizing an Innovative Approach to Investment Agreements, EJIL: TALK! (Sept. 12, 2017) (citing the Olivos Protocol for the Settlement of Controversies in MERCOSUR, Art. 1(2), Feb. 2, 2002, 2251 UNTS 243, as amended. See also The Southern Common Market (MERCOSUR): Protocol of Colonia for the Promotion and the Reciprocal Protection of Investments in the MERCOSUR, MERCOSUR/CMC/DEC No. 11/94 (Jan. 17, 1994), available at https://legislativo.parlamento.gub.uy/temporales/S2018050635-001827341.pdf\#page=.

${ }^{153}$ See, e.g., Brazil-Mozambique Agreement on Cooperation and Facilitation of Investment Agreement, Art. 15, Mar. 20, 2015, available at http://www.itamaraty.gov.br/index.php?option=com_content\&view=article $\&$ $\mathrm{id}=8511 \&$ catid $=42 \&$ Itemid $=280 \&$ lang $=\mathrm{pt}-\mathrm{BR}$.
} 


\section{Trade-offs of political mechanisms}

Reliance on negotiation and mediation should be less likely to promote broader rule of law practices within domestic governance institutions since conflicts would be resolved in light of political objectives shaped by relative power. Fairness toward affected stakeholders would only be addressed as a function of their representation by states. Negotiations might be conducted in the shadow of the law, but references to the law might be just self-serving, cheap talk. Because of the uncertainty of these processes, they also would less likely advance the goal of reducing the cost of investment capital. These political options, however, could be cheaper since the parties would avoid the high costs associated with litigation. ${ }^{154}$ The host state could then use its resources in other more productive ways.

Although diplomacy may work in some instances, it also can be complex, costly, and opaque. The more difficult that it is to understand channels of influence, the costlier it is for investors to organize for political action. Small- and medium-sized investors are likely to be particularly disadvantaged because they have less political access to state officials-who prioritize the deployment of state resources based on economic weight and systemic importance. ${ }^{155}$ In contrast, well-organized actors with substantial stakes are better positioned to trigger a response from the home state. Thus, when this institutional option is used successfully on behalf of an investor, it may be biased in favor of those investors with substantial stakes, reflecting minoritarian bias. When it fails to benefit an unjustly treated investor, it could reflect majoritarian bias.

\section{Domestic Dispute Settlement Mechanisms}

\section{Courts, specialized processes, and ombudsman offices}

Domestic dispute settlement mechanisms are the first (and fallback) option for resolving investment disputes through adjudication if negotiations fail. Domestic law can delegate investment disputes to specialized domestic courts and other institutions because of their expertise and to counter bias against outsiders. ${ }^{156}$ Iraq and Kazakhstan, for example, created specialized investment courts to hear disputes between investors and investment authorities for these reasons. ${ }^{157}$ Other countries use alternative dispute resolution mechanisms,

\footnotetext{
${ }^{154}$ According to some reports, the costs of ISDS "have averaged over USD 8 million with costs exceeding USD 30 million in some cases." David Gaukrodger \& Kathryn Gordon, Investor-State Dispute Settlement: A Scoping Paper for the Investment Policy Community 1, 19 (OECD Working Papers on Int'l Inv., 2012/03, 2012), available at http://www.oecd.org/daf/inv/investment-policy/WP-2012_3.pdf. See also United Nations Conference on Trade \& Development, Investor-State Disputes: Prevention and Alternatives to Arbitration 16-18 (2010), available at http://unctad.org/en/Docs/diaeia200911_en.pdf.

155 Sykes, supra note 67, at 653 (explaining options of ex post political filters). Interview with Official of the European Commission, Brussels (May 16, 2018) (on file with authors).

${ }^{156}$ In the United States, concerns over local bias motivated the creation of federal courts. As Madison wrote regarding the reason for Article III of the U.S. Constitution, which confers federal judicial power over disputes between "a State, or the Citizens thereof, and foreign States, Citizens or Subjects," was that "foreigners cannot get justice done in [state] courts.” 3 The Debates in the Several State Conventions on the Adoption of the Federal Constitution 583 (Jonathan Elliot ed., 2d ed. 1876) (quoting Madison).

${ }^{157}$ For Iraq, see U.S. Department of State, 2017 Investment Climate Statements (June 29, 2017), at https:// www.state.gov/e/eb/rls/othr/ics/2017/nea/269978.htm. For Kazakhstan, see Elmira Kirgeyeva, It Is Offered to Establish an Investment Court in Kazakhstan, KazPravda (Feb. 12, 2015), at http://www.kazpravda.kz/en/news/ economics/it-is-offered-to-establish-an-investment-court-in-kazakhstan.
} 
including (more recently) an investment ombudsman office. ${ }^{158}$ Morocco and South Korea mandate institutionalized mediation before a domestic institution-respectively, the Moroccan Investment Development Agency and the Korean Commercial Arbitration Board-prior to adjudication. ${ }^{159}$

Domestic dispute settlement mechanisms can apply international law as part of domestic law. Depending on the state's constitutional system, a domestic court can apply international law directly as part of the domestic legal system or indirectly through domestic implementing legislation. ${ }^{160}$ Thus, a national court or domestic authority may be able to decide the investment dispute by reference to a treaty or customary international law.

\section{Trade-offs of domestic dispute settlement mechanisms}

Using domestic mechanisms, at least as a first instance, offers comparative advantages. First, the rule of law, broadly understood, depends on qualified, independent, impartial domestic dispute settlement institutions that can address the claims of all affected stakeholders. An advantage of addressing these claims together, including any counterclaims by the state or affected individuals or communities, is that a single forum can hear them. Relatedly, a broader range of actors have access to domestic proceedings so that more voices can be heard by decision-makers, which promotes fairness. Since a single venue would hear the claim, the process also could be more efficient. Domestic institutions are relatively more available to hear smaller cases that are important to smaller investors. International investment law's effectiveness thus is bolstered by domestic mechanisms. ${ }^{161}$ Where a critical mass of actors uses domestic institutions to resolve investment disputes, these institutions can develop expertise and a professional ethos and reputation. Domestic institutions with these characteristics are more likely to be accepted as legitimate venues for resolving claims than a remote international body. This, in turn, can facilitate enforcement and compliance.

The effective use of domestic mechanisms also can help to incentivize investment and support economic growth, thereby reducing a country's cost of capital. A state that wishes to reduce its cost of capital thus has an incentive to invest in domestic institutions to uphold the rule of law. In contrast, automatic resort to international dispute settlement as a substitute for domestic mechanisms could reduce pressure to create national institutions that are independent and can hold governments accountable. ${ }^{162}$

\footnotetext{
${ }^{158}$ UNCTAD, Investor-State Disputes: Prevention and Alternatives to Arbitration 92 (2010), available at http://unctad.org/ en/Docs/diaeia200911_en.pdf (noting that "several States have set up institutions to provide internal mediation services or designate official mediators available for foreign investors").

${ }^{159}$ For South Korea, see Françoise Nicolas, Stephen Thomsen \& Mi-Hyun Bang, Lessons from Investment Policy Reform in Korea 23, 25 (OECD Working Papers on Int'l Inv., 2013/02, 2013), available at http://www.oecd.org/ daf/inv/investment-policy/WP-2013_2.pdf (explaining that an ombudsman can help ensure "foreign investors" opinions are heard at the highest levels of policy-making"). On Morocco, see, e.g., Tarcisio Gazzini, Nigeria and Morocco Move Towards a "New Generation" of Bilateral Investment Treaties, EJIL: TALK! (May 8, 2017) (discussing "disputes prevention” mechanism).

${ }^{160}$ See Eyal Benvenisti, Reclaiming Democracy: The Strategic Uses of Foreign and International Law by National Courts, 102 AJIL 241, 242 (2008).

${ }^{161}$ David Sloss, Treaty Enforcement in Domestic Courts: A Comparative Analysis, in The Role of DomestiC Courts in Treaty Enforcement: A Comparative Study (David Sloss ed., 2009) (analyzing the varied role of domestic courts in hearing "vertical" claims between a State and private persons).

${ }^{162}$ See infra section IV(F) [discussing international mechanisms as substitutes].
} 
The internationalization of investment disputes, however, is a response to real deficiencies in many judicial systems and concerns over the impartiality of domestic authorities. From the perspective of capital exporting countries, national courts in many developing countries are unable to provide speedy, neutral, and technically competent resolution of investment claims. ${ }^{163}$ In these situations, investors prefer enforcement outside of local institutions to ensure fairness. Historically, developing countries have agreed to these processes in part because of power dynamics, but also often because they know that their domestic judicial systems can fail to provide such assurances.

Domestic mechanisms also are prone to majoritarian bias and minoritarian bias. Local majorities can inflict high costs on investors where a single investor with high per capita stakes is on one side, and, on the other side, are large groups with low per capita stakes. Domestic authorities may not be able to withstand pressure to adopt popular decisions at the investor's expense. At other times, domestic minoritarian interests may convince local authorities to take unfair or discriminatory action against a foreign investor. On the other hand, although one always can find examples of minoritarian bias, many studies find that foreign firms, on average, are treated at least the same or even better than domestic firms, such that the alternative of ISDS provides them with an even greater advantage. ${ }^{164}$ The choice of this option thus depends on context and, once again, its comparison with other institutional alternatives.

\section{Independent Interstate Adjudicatory Mechanisms}

In the investment context, a state can be sued before an international court or tribunal with jurisdiction when another state asserts diplomatic protection on behalf of its nationals. In espousing an investor's claim, the state operates independently of the investor, which has no direct control over the claim, unlike the other adjudicatory mechanisms we assess. Interstate adjudication of investment disputes generally does not result from acceptance of an international court's jurisdiction before a dispute arises. Rather, states more commonly make arrangements after the conduct at issue occurs by creating ad hoc tribunals or consenting to jurisdiction for a specific case. Nonetheless, permanent bodies such as the ICJ or the WTO have heard some investment-related complaints.

\section{Ad hoc tribunals}

States have periodically created international claims commissions and ad hoc arbitral tribunals to adjudicate cases involving the seizure and mistreatment of foreign-held property. ${ }^{165}$ In many of these instances, states established a semi-permanent body where only states have standing and control the selection of arbitrators. Some of these tribunals have been created

163 Cristoph H. Schreuer, The ICSid Convention: A Commentary 5 (2001). ("Rightly or wrongly, the national courts of one of the disputing parties are not perceived as sufficiently impartial.”).

${ }^{164}$ However, a number of studies find that foreign firms tend to be treated at least the same or even better than domestic firms. See, e.g., Bonnitcha, Poulsen \& Waibel, supra note 87, at 149-51.

${ }^{165}$ MiLes, supra note 8, at 67-69 (noting examples of mixed claims commissions including those established to handle disputes between France-Venezuela, Iran-United States, United States-Germany, Mexico-United States, and Iran-United States). In addition, interstate arbitration can and periodically still does take place under BITs. In 2011, for example, Ecuador launched a state-to-state arbitration seeking to clarify interpretation in a treaty with the United States. See Ecuador v. United States, PCA Case No. 2012-5, Request for Arbitration, para. 1 (Perm. Ct. Arb. 2011). 
following mediation or peace agreements involving diplomatic efforts and sometimes coercion. The best-known example of interstate ad hoc adjudication of investment disputes because of its duration and number of awards is the Iran-U.S. Claims Tribunal. The tribunal was created pursuant to the Algiers Accords after Iran held U.S. embassy officials as hostages and nationalized the assets of U.S. companies, and the United States, in turn, froze around US $\$ 11$ billion of Iranian assets held in U.S. banks. ${ }^{166}$ During the 1980s and 1990s, the Iran-U.S. Claims Tribunal created a huge body of investment law jurisprudence that laid important groundwork for ISDS case law. ${ }^{167}$

The United States and Europe have generally stopped espousing investor claims, and, with ISDS, they have little reason to do so. ${ }^{168}$ The United Kingdom, for example, wound up its Foreign Compensation Commission, sending a general message that its investors are on their own (i.e., should rely on BITs) to resolve disputes. ${ }^{169}$ The United States still espouses investor claims, but its policy shifted so that it does not espouse a claim if the investor has other options available, such as before local courts or ISDS. Some states, however, have recently advocated for interstate alternatives to ISDS. ${ }^{170}$ Brazil's ACFI, for example, only provides for state-tostate adjudication, and it does not grant the tribunal jurisdiction to determine damages unless the home and host state consent and only after the investor's withdrawal of damages claims before domestic tribunals. ${ }^{171}$ South Africa's Protection of Investment Act of 2015 provides that the government may consent to state-to-state dispute settlement, rather than ISDS, subject to the exhaustion of local remedies. ${ }^{172}$

\section{International courts}

Modern BITs have antecedents in FCN treaties, and some of these treaties provided for interstate dispute resolution before the ICJ. Very few cases before the ICJ, however, have involved the treatment of foreign investment. In the Barcelona Traction case, the Court found that the treaty at issue provided limited rights for shareholders, and it set a high bar for legal standing to invoke state responsibility on their behalf. ${ }^{173}$ Capital exporting countries,

${ }^{166}$ Robert Owen, The Final Negotiation and Release in Algiers, in American Hostages In Iran: The Conduct OF A CRISIs 297, 312 (Warren Christopher \& Paul H. Kreisberg eds., 1985).

167 George H. Aldrich, The Jurisprudence of the Iran-United States Claims Tribunal (1996); David D. Caron, The Nature of the Iran-United States Claims Tribunal and the Evolving Structure of International Dispute Resolution, 84 AJIL 104, 156 (1990) (noting that ICSID is part of an "evolving system" that included the Tribunal and "millions" spent on its operation and hundreds of awards rendered).

${ }^{168}$ As the ICJ noted in 2007, diplomatic protection under BITs has "somewhat faded, as in practice recourse is only made to it in rare cases where treaty regimes do not exist or have proved inoperative." See Ahmadou Sadio Diallo (Guinea v. Dem. Rep. Congo), Preliminary Objections, 2007 ICJ Rep. 582, 614, para. 88 (May 24).

${ }^{169}$ United Kingdom Secretary for Foreign and Commonwealth Affairs, Fifty-Fourth Annual Report of the Foreign Compensation Commission for the Fiscal Year Ended 31 March 2009 (2010), at https://www.gov.uk/government/publications/foreign-compensation-commission-fcc.

170 See, e.g., SADC Model Bilateral Investment Treaty Template, S. Afr. Dev. Community, Art. 29 (July 2012) (members include Zimbabwe, Botswana, Zambia, Tanzania, Angola, Mozambique, Malawi, Lesotho, and Swaziland), available at http://www.iisd.org/itn/wp-content/uploads/2012/10/sadc-model-bit-template-final. pdf.

${ }^{171}$ Brazil ACFI supra note 43, Art. 24. See, e.g., Brazil-Mozambique Cooperation and Facilitation Agreement, Art. 15 (Mar. 30, 2015), available at http://investmentpolicyhub.unctad.org/Download/TreatyFile/4717.

172 South Africa Protection of Investment Act 22, supra note 43.

${ }^{173}$ Barcelona Traction, Light and Power Co., Ltd. (Belg. v. Spain) (Second Phase), 1970 ICJ Rep. 3, 32 (Feb. 5). 
lobbied by multinational corporations, thus turned to more specialized bodies to resolve investment conflicts.

In 1995, states created the WTO, the multilateral trade organization with a compulsory dispute settlement system. The WTO covers some investment-related disciplines in different agreements. The General Agreement on Trade in Services (GATS) addresses the establishment of a "commercial presence" in WTO members to provide services (i.e., an investment). The Agreement on Trade-Related Investment Measures (TRIMS) prohibits investment measures that favor the use of domestic products over foreign ones, such as through domestic content regulations. The Agreement on Trade-Related Aspects of Intellectual Property Rights (TRIPS) prescribes rules protecting patents, copyrights, trademarks, and other intellectual property. Some WTO members have continued to advocate for additional coverage of investment issues. ${ }^{174}$ Any WTO member can activate the WTO system of interstate adjudication, which does not require the exhaustion of local remedies. Its two-tier process includes an appellate body, which provides a precedent for the EU's proposed multilateral investment court system. Indeed, rather than creating a new international organization with a new secretariat, an investment court could be housed at the WTO, which some favor. ${ }^{175}$

A few WTO disputes have involved investment-related issues, including regarding GATS, TRIMS, and TRIPS, and a few of them were litigated in parallel to ISDS cases. ${ }^{176}$ However, because WTO claims are limited to the WTO covered agreements and because many countries' commitments under the GATS are limited, WTO cases generally have not addressed the most frequently litigated ISDS claims regarding fair and equitable treatment and expropriation. They rather have involved claims over intellectual property and non-discrimination, especially since BITs and ISDS panels have adopted expansive definitions of "investment." The most noteworthy case is Australia-Plain Tobacco Packaging where the WTO and ISDS claims were largely analogous, based on an alleged indirect expropriation of a Philip Morris brand (under the BIT claim) and the encumberment of the trademark (under the WTO TRIPS claim). ${ }^{177}$ There also have been parallel ISDS and WTO national treatment cases based on the same government measure, with the WTO cases addressing discrimination against traded goods and the ISDS ones involving discrimination against the foreign investor. ${ }^{178}$ Analogously, there were both WTO and ISDS claims brought against Mexico's

${ }^{174}$ In 2017, twelve emerging economies, including Brazil, China, Mexico, and Pakistan, created a new group in the WTO named Friends of Investment Facilitation for Development to advance new investment-related proposals. See World Trade Organization, Trade and Investment Topics, at https:/www.wto.org/english/tratop_e/ invest_e/invest_e.htm.

${ }^{175}$ Interview with Official of the European Commission, supra note 155.

176 See, e.g., Panel Report, Canada-Certain Measures Affectingthe Automotive Industry, WT/DS139/R, WT/DS142/R (adopted June 19, 2000), as modified by Appellate Body Report WT/DS139/AB/R, WT/DS142/AB/R, DSR 2000: VII, at 10.58-.150 (involving investment related measures under TRIMS and GATT); Australia Certain Measures Concerning Trademarks and Other Plain Packaging Requirements Applicable to Tobacco Products and Packaging, WT/DS434 (Ukraine), WT/DS435 (Honduras), WT/DS441 (DR), WT/DS458 (Cuba), WT/DS467 (Indonesia) (involving IP related measures under TRIPS); United States - Measures Concerning Non-immigrant Visas, Request for Consultations by India, WT/DS503/1/Add.1 (Mar. 18, 2016) (involving measures under GATS).

177 Cf. Australia - Certain Measures, supra note 176; Philip Morris Asia v. the Commonwealth of Australia, Philip Morris Asia Notice of Arbitration, paras. 7.15-.17 (UNCITRAL Nov. 21, 2012).

${ }^{178}$ For example, American fructose producers brought three ISDS cases against Mexico in response to a Mexican tax on soft drinks with an exemption for those using cane sugar (which came from Mexican producers), while the United States successfully brought a WTO claim against the same discriminatory tax. The U.S.-Canada 
telecommunications regulations that favored the Mexican quasi-monopolist Telmex. ${ }^{179}$ More generally, WTO Appellate Body jurisprudence upholding non-discriminatory state regulation has been cited and arguably influenced ISDS cases regarding the need for balance in recognizing a state's right to regulate. ${ }^{180}$

\section{Trade-offs of independent interstate adjudicatory mechanisms}

These two types of interstate options_-ad hoc tribunals and permanent courts—present similar trade-offs, but they also exhibit some important differences. Both permanent and ad hoc bodies can provide some support for adherence to the rule of law, and thus provide some assurance of fair treatment of investors. However, a permanent international court hearing investment claims offers certain advantages over ad hoc dispute settlement. First, it can create greater certainty that claims may be brought, since no further negotiations are needed to create the tribunal. Second, a multilateral dispute settlement mechanism, as under the WTO, can cover the major nations of the world, operate iteratively over time in clarifying and enforcing legal commitments, and thus have more normative authority than ad hoc bodies. ${ }^{181}$ This is particularly the case of an international mechanism with an appeals system, such as the WTO Appellate Body, which has generated a substantial and influential jurisprudence, including regarding a state's right to regulate. ${ }^{182}$ As a result, permanent interstate bodies could better facilitate the diffusion of norms of fairness, helping to enhance rule-of-law accountability in domestic jurisdictions.

Interstate adjudicatory mechanisms both offer benefits and raise concerns because of state control of the process. On the one hand, states may represent the broader interests of their citizens, as opposed to only investor commercial interests. Because interstate alternatives constrain access to dispute settlement, they create an opportunity for states to screen controversial, overly aggressive, or illegitimate claims. ${ }^{183}$ Moreover, this alternative permits states to control the arguments brought before tribunals regarding the interpretation of the treaty they negotiated. This power is important, since in many instances states could be on either side of investment claims — as a defendant or as a complainant espousing a national's claims.

softwood lumber saga also included parallel ISDS and WTO claims for violation of national treatment clauses. Nicholas DiMascio \& Joost Pauwelyn, Nondiscrimination in Trade and Investment Treaties: Worlds Apart or Two Sides of the Same Coin? 102 AJIL 48, 49-50 (2008) (on the sweeteners and lumber disputes).

${ }^{179}$ See Mexico - Measures Affecting Telecommunications Services, WT/DS204/3 (Feb. 18, 2002); Notice of Intent, Telefónica S.A. v. United Mexican States, ICSID Case No. ARB(AF)/12/4, available at https://www.italaw.com/sites/default/files/case-documents/ita1040.pdf.

${ }^{180}$ See, e.g., Continental Casualty Co. v. Argentine Republic (U.S. v. Arg.), ICSID Case No. ARB/03/9, Award, 87 (Sept. 5, 2008), available at http://italaw.com/sites/default/files/case-documents/ita0228.pdf. See generally Greg Tereposky \& Morgan Maguire, Utilizing WTO Law in Investor State Dispute Settlement, in Contemporary Issues in International Arbitration and Mediation: The Fordham Papers 2010, at 247 (Arthur Rovine ed., 2011).

${ }^{181}$ See Gregory Shaffer, Manfred Elsig \& Sergio Puig, The Extensive (but Fragile) Authority of the WTO Appellate Body, 79 L. \& Contemp. Probs. 237, 271 (2016).

182 Robert Howse, The World Trade Organization 20 Years On: Global Governance by the Judiciary, 27 EUR. J. INT'L L. 9 (2016).

${ }^{183}$ For example, the case brought by Eli Lilly challenging a Canadian Supreme Court's decision regarding the criteria of patentability, and the case brought by Philip Morris against Uruguayan regulatory measures advocated by the World Health Organization have been hugely controversial. See Eli Lilly and Co. v. The Government of Canada, ICSID Case No. UNCT/14/2, Final Award (Mar. 16, 2017); FTR Holding S.A., Philip Morris Products S.A. (Switz.) \& Abal Hermanos S.A. (Uru.) v. Uruguay, ICSID Case No. ARB/10/7 (2010), Award (July 8, 2016). 
Having states act as filters can be beneficial because it eliminates corporate actors' ability to aggressively pursue adjudication through ISDS — whether to bargain in the law's shadow, counter prospective regulation through the threat of an expensive lawsuit, or to shape the law's interpretation - and can thus be relatively less biased against states and the other stakeholder interests that states represent. Because states retain control of dispute settlement, they can focus on long-term mutual gains, rather than short-term victories in investment disputes.

On the other hand, because the system is state-based, it retains a political/diplomatic dimension and thus does not focus directly on the fair treatment of private parties, nor on enhancing the rule of law in domestic jurisdictions. States may sacrifice a private party's interests and decide not to bring a claim. ${ }^{184}$ In addition, states control the selection of judges, so that the judges in these bodies may have only moderate independence. ${ }^{185}$ Moreover, remedies issued by interstate bodies may not benefit the harmed investor. The primary WTO remedy, for example, is the withdrawal of equivalent concessions by the complaining state, which provides no compensation to the aggrieved private party. ${ }^{186}$ In consequence, investors could be warier about investing in the state in question, potentially increasing that state's cost of capital. Finally, in terms of international relations, this mechanism may be less likely to depoliticize a conflict since the bringing of claims by one state against another could be viewed as an unfriendly, political act, at least more so than when an investor brings the claims on its own. ${ }^{187}$

In terms of participation and bias, because states exercise discretion as to whether to espouse a claim, participation will more likely be skewed in favor of well-connected private parties. States may only espouse claims of nationals that are politically influential and vociferously lobby them. They may only represent claims of large companies, so that small- and medium-sized companies' claims are sacrificed in the interest of interstate relations, and hence result in minoritarian bias. International adjudicatory bodies (whether permanent or ad hoc) also could exhibit bias in favor of powerful states, such as to ensure their support for the overall system so that it does not collapse. ${ }^{188}$ Yet, once again, the benefits and deficiencies of this

\footnotetext{
${ }^{184}$ Stephan Schill, Enhancing the Legitimacy of International Investment Law: Conceptual and Methodological Foundations of a New Public Law Approach, 52 VA. J. INT'L L. 57, 68 (2011) ("While this solution would allow states to exclude spurious or frivolous claims, it would equally permit them to discard claims for foreign policy reasons."); J.L. Brierly, The LaW Of Nations 277 (6th ed. 1963) (arguing that state-to-state procedure "is far from satisfactory from the individual's point of view. He has no remedy of his own, and the state to which he belongs may be unwilling to take up his case for reasons which have nothing to do with its merits.").

185 Cf. Eric A. Posner \& John C. Yoo, Judicial Independence in International Tribunals, 93 CAL. L. REv. 1 (2005) (judges are "independent" when they "are appointed in advance of any particular dispute and serve fixed terms"); Laurence R. Helfer \& Anne-Marie Slaughter, Why States Create International Tribunals: A Response to Professors Posner and Yoo, 93 CAL. L. Rev. 899 (2005) (discussing political constraints that operate on international courts and tribunals.)

186 See Sykes, supra note 67, at 643-44. See also Brazil's ACFI where the remedy focuses on compliance, supra note 43.

187 See, e.g., Hersch Lauterpacht, The Subjects of the Law of Nations, 63 L. Q. REv. 438, 454 (1947), reprinted in 2 International Law, Being the Collected Papers of Hersch Lauterpacht 487, 504 (Elihu Lauterpacht ed., 1975) (arguing that the espousal of a claim by the state tends to impart the complexion of political controversy and unfriendly action).

${ }^{188}$ See, e.g., Richard H. Steinberg \& Jonathan M. Zasloff, Power and International Law, 100 AJIL 64, 74 (2006) ("state behavior and associated international outcomes may appear to be shaped by international law, but because international law mirrors the interests of powerful states, international law is merely an epiphenomenon of underlying power").
} 
alternative must be assessed against those besetting other decision-making processes in light of particular contexts.

\section{E. International Adjudicatory Mechanisms as Substitutes}

The proliferation of ISDS cases and large damage awards has catalyzed debates over institutional reform, notably over whether to create a multilateral investment court system. Although both ISDS and such a system could operate as complements to domestic mechanisms, we address the two options as substitutes because that is how they have been proposed and operated. ${ }^{189}$

\section{Ad hoc tribunals-ISDS}

ISDS is the dominant method for international investment adjudication today. Thousands of BITs provide for it, as do many free trade agreements such as NAFTA. ISDS is a mechanism through which investors may directly obtain damages from states for breaches of international investment law by bringing claims to an arbitral panel. ${ }^{190}$ ICSID provides the main pillar for ISDS, although approximately 39 percent of proceedings take place outside of ICSID, such as through the Permanent Court of Arbitration in the Hague, the Stockholm Chamber of Commerce, and other bodies. ${ }^{191}$ Individual arbitrations have produced awards of over a billion dollars, and numerous awards are in the hundreds of millions. ${ }^{192}$ The awards are binding on the parties and not subject to appeal or to any other checks except on very limited grounds. ${ }^{193}$

\section{Trade-offs of ISDS}

ISDS offers many institutional advantages, especially for investors. Compared to domestic mechanisms, ISDS guarantees foreign investors access to a specialized adjudicatory process that is independent of national authorities. It provides an alternative where domestic systems lack reliable, quality, impartial courts. Compared to the interstate alternative, the investor has a private right of action and does not depend on the state to espouse its claim. It is thus viewed

189 See Tom Ginsburg, International Substitutes for Domestic Institutions: Bilateral Investment Treaties and Governance, 25 INT'L REv. L. \& ECON. 107, 108 (2005) (concluding that in many cases BITs with ISDS operate as substitutes, rather than compliments, of local institutions); Center for International Environmental Law, Position Paper: EU Proposal for a Multilateral Reform of Investment Dispute Resolution, at 5 (Mar. 15, 2017) (criticizing the proposal for "allowing investors to side step" domestic courts).

${ }^{190}$ ICSID arbitration tribunals are typically composed of three members. Both the investor and the state select one arbitrator and they jointly agree on a third arbitrator as chair, failing which the chair is selected by the president of the World Bank (or, in some instances, the co-arbitrators). ICSID Convention, supra note 19, Arts. 37-38. In practice, the secretary-general of ICSID recommends a chair to the World Bank president.

${ }^{191}$ UNCTAD, Special Update, supra note 26.

${ }^{192}$ Id. at 5 (noting that between 1987-2017, "in cases decided in favour of the investor, the average amount claimed was $\$ 1.35$ billion and the median $\$ 113$ million. The average amount awarded was $\$ 522$ million and the median \$19 million”).

${ }^{193}$ ICSID Convention, supra note 19, Art. 52 (providing for annulment of an award on five limited grounds). ICSID's Additional Facility (AF), which can be used by non-ICSID members, does not grant arbitration awards the benefit of ICSID annulment procedures. See ICSID, Additional Facility Rules, ICSID Doc. ICSID/11 (2006). In the latter case, ICSID awards are subject to review by national courts. However, the New York Convention on the Recognition and Enforcement of Foreign Arbitral Awards limits the scope of national court review if the state is a party to that convention. 
as a more legal and less political process than interstate dispute settlement. ${ }^{194}$ Accordingly, ISDS should be more attractive to investors, although the investor must cover its share of the cost of arbitration.

To the extent that ISDS provides greater assurances to investors that they will be fairly treated in accordance with basic rule-of-law protections, ISDS could help states to attract investment, thus contributing to resource allocation efficiency and aggregate national welfare. In addition, from the perspective of interstate relations, ISDS compartmentalizes conflicts between states by providing investors with legal standing to bring claims. To some, it thus appears superior from the perspective of interstate conflict avoidance. ${ }^{195}$

ISDS is also subject to disadvantages in terms of investment law's goals. From the perspective of fairness, many contend that ISDS is biased in favor of investors. ${ }^{196}$ From the perspective of the rule of law, since ISDS decisions are made on an ad hoc basis and are not subject to appeal, they have resulted in many inconsistencies and contradictions, such that like cases are not decided alike. ${ }^{197}$ From the perspective of resource allocation efficiency, since countries balance investment promotion against other social welfare goals, if ISDS is biased against other state social welfare policies, then any additional investment is not optimal. ${ }^{198}$ Moreover, ISDS jurisprudence generated by investor claims, has created considerable uncertainty, both because of its inconsistencies and because it frequently calls into question contractual commitments that are overridden by BIT claims. ${ }^{199}$ In addition, empirical studies question whether BITs with ISDS, in fact, lead to greater foreign direct investment. ${ }^{200}$ From the perspective of depoliticization, investors at times bring claims that implicate highly sensitive domestic policies, thus increasing conflict and political tension.

Perhaps most importantly, the rule of law ultimately depends on domestic governance, but ISDS has operated as a substitute for local courts. Article 26 of the ICSID Convention does not require "exhaustion of local administrative or judicial remedies" "unless otherwise stated" in a treaty, and in practice most BITs do not require it. ${ }^{201}$ Indeed, for years ICSID highlighted the importance of abstention from domestic courts as "essential to the proper implementation” of ISDS. ${ }^{202}$ In fact, many BITs contain a fork-in-the-road provision that can be fatal to

194 Reisman Opinion, supra note 23, para. 37 (noting ISDS as removing "the caprice of sovereign-to-sovereign
politics").
${ }_{195}$ Roberts, Triangular Treaties, supra note 73, at 378-80.
196 See supra section I(B).
197 See Franck supra note 35, at 1545-54 (discussing options to address inconsistencies). Cf. STONE SWEET \& GRISEL, supra note 58, at 220 ("[t]he more the judicial model has been institutionalized, the more inconsistent decisions are treated as signatures of (treatable) pathology"); Laurence Boisson de Chazournes, Plurality in the Fabric of International Courts and Tribunals: The Threads of a Managerial Approach, 28 EuR. J. INT'L L. 13, 46 (2017) (explaining how procedural mechanisms are being used to a greater extent to mitigate inconsistencies).

198 See supra section II(A).

199 See Julian Arato, The Logic of Contract in the World of Investment Treaties, 58 WILliam \& MARY L. REV. 351, 351-52 (2016) ("arbitral jurisprudence has varied wildly on this point, creating significant problems of certainty, efficiency, and fairness - for states and foreign investors alike”).

${ }^{200}$ UNCTAD, The Impact of International Investment Agreements on Foreign Direct Investment: An Overview of Empirical Studies 1998-2014 (Sept. 2014) (reviewing thirty-five published and unpublished studies).

${ }^{201}$ ICSID Convention, supra note 19, Art. 26. For practice, see DOLzer \& SCHREUER, supra note 20, at 268.

202 See Georges R. Delaume, ICSID Arbitration and the Courts, 77 AJIL 784, 785 (1983); B. P. Marchais, ICSID and the Courts, News OF ICSID 4 (1986). 
the use of investor-state arbitration under a BIT. ${ }^{203}$ Where ISDS discourages a relationship of complementarity with domestic courts, it can reduce the pressure for domestic rule-of-law reforms. ${ }^{204}$ It thus tends to promote exit (from domestic legal systems) over voice (in domestic law reform debates). ${ }^{205}$

In terms of participation and bias, adjudication can offer the advantage of evenhandedness and legal reasoning to counter potential majoritarian bias against investors. ISDS, however, involves high access costs, is removed from mass publics, and is commonly charged with failure to appropriately balance competing interests, in part because of the inability of states and other stakeholders to raise claims and counterclaims against investors. ${ }^{206}$ Moreover, unlike judges, arbitrators in ISDS are nominated by the parties. This selection process may shape their dispositions, reflecting different forms of bias—categorized as selection, compensation, and affiliation bias. ${ }^{207}$ Some arbitrators represent and consult for private clients in their legal practice, and thus may face conflicts of interest. ${ }^{208}$ Structurally, since the ISDS system is highly remunerative for private practitioners, and since the arbitrators are paid on a caseby-case basis (and by the hour), the arbitrators have an incentive to ensure the future flow of claims. ISDS thus can lead to minoritarian bias in favor of investors, especially those that are well-organized, because they have high per capita stakes, compared to other stakeholders that are numerous but disorganized due to their low per capita stakes.

\section{International courts - multilateral investment court system}

Because of the criticisms of ISDS, the EU and many commentators have advocated for the creation of a specialized court containing an appellate body. What the EU proposal and ISDS have in common is a private right of standing to bring international claims directly against states. ${ }^{209}$ They differ in their form—-mainly, ad hoc arbitration versus a two-tier system with a standing court and appeals court. At the outset, it is important to note that if a multilateral

${ }^{203}$ Kenneth J. Vandevelde, The Bilateral Investment Treaty Program of the United States, 21 CORNELL INT'L L.J. 201, 258, 263-64 (1988) (explaining that fork-in-the-road requires an investor to choose to submit a claim either before domestic courts or international arbitration).

${ }^{204}$ See, e.g., Anne van Aaken, The Interaction of Remedies Between National Juridical Systems and ICSID: An Optimization Problem, in The Future of ICSID and the Place of Investment Treaties in International LAW 291, 324 (N. Jansen Calamita, David Earnest \& Markus Burgstaller eds., 2013) ("This deprives the State of the opportunity to reconsider its decision through administrative or judicial review and grant primary remedies. A better solution would be to allow for review of a government measure under domestic law without construing such a challenge as a violation of the BIT protections.").

${ }^{205}$ A. O. Hirschman, Exit, Voice, and Loyalty: Responses to Decline in Firms, Organizations, and States (1970).

206 There are exceptions and ISDS respondents bring counterclaims, but they are typically unsuccessful. See, e.g., Perenco Ecuador Ltd. v. Republic of Ecuador, ICSID Case No. ARB/08/6, Environmental Counterclaim, para. 447 (Aug. 11, 2015), IIC 699 (2015). For an extensive discussion, see, Frederic Gilles Sourgens, Supernational Law, 50 VAND. J. TRANSNAT'L L. 155 (2017).

${ }^{207}$ Puig, supra note 36, at 661 (discussing biases in ISDS). See also Sergio Puig \& Anton Strezhnev, Affliation Bias in Arbitration: An Experimental Approach, 46 J. LegAL STUd. 371 (2017) (providing evidence of bias).

${ }^{208}$ Langford, Behn \& Lie, The Revolving Door, supra note 36 (providing empirical evidence of double-hatting); Nassib G. Ziadé, How Many Hats Can a Player Wear: Arbitrator, Counsel and Expert?, 24 ICSID Rev._For. INV. L.J. 49 (2009).

209 See, e.g., Negotiating Directives for a Convention Establishing a Multilateral Court for the Settlement of Investment Disputes, 12981/17 ADD 1 RESTREINT UE/EU RESTRICTED, March 1, 2018. See also European Commission, Reading Guide, European Commission Fact Sheet - Reading Guide (Sept. 16, 2015), available at http://europa.eu/rapid/press-release_MEMO-15-5652_en.pdf. 
international court system is created, as through the UNCITRAL process, it could potentially depart from the EU proposed model in significant ways. ${ }^{210}$ Analysis should thus include how the EU proposal may be adapted. ${ }^{211}$

The EU proposal is not the first for a permanent investment court. ${ }^{212}$ Notably, the 1974 Convention of the Settlement of Investment Disputes between Host States of Arab Investments and Nationals of Other Arab States created the Arab Court of Investment, which is now active. ${ }^{213}$ Unlike this regional system, however, the system pursued by the EU bilaterally and multilaterally has the potential to extend beyond a discrete geographical region and be widely used.

The EU is incrementally creating a base for such a system through signing bilateral agreements, such as with Canada, Mexico, Singapore, and Vietnam, ${ }^{214}$ while the EU continues to promote the multilateral investment court system in parallel. These agreements are pending ratification by each of the EU member states, which will take time, and Belgium has requested the Court of Justice of the European Union (CJEU) to issue an opinion regarding the compatibility with EU law of CETA's provisions regarding an investment court system. ${ }^{215}$ Under these agreements, claims are to be heard by three-member divisions of a permanent court, which would replace the system of party appointments. ${ }^{216}$ The court's decision is subject to appeal before a tribunal comprised of six members who must "have demonstrated expertise in public international law." 217 The grounds for appeal include errors of law and manifest errors of fact, in addition to the grounds provided in Article 52 of the ICSID Convention. ${ }^{218}$ The appeal tribunal would have the power to "modify or reverse" the panel's decision or remand it for further consideration. The contracting states would select the members of the court and appeal tribunal, who would be paid a regular salary, enjoy security of tenure for a fixed, non-renewable term (around four to five years), and be subject to a set of ethical obligations to ensure independence and impartiality. ${ }^{219}$ If the multilateral investment court system draws from this model, many further procedural details remain to be determined

${ }^{210}$ Roberts, supra note 1, at 419-21.

${ }^{211} I d$. at 412-23.

212 Taylor St John \& Yulia Chernykh, Déjà Vu? Investment Court Proposals from 1960 and Today, EJIL: TALK! (May 15, 2018), at https://www.ejiltalk.org/deja-vu-investment-court-proposals-from-1960-and-today (explaining that "in the 1950s and 1960s, eminent international lawyers from around the world ... discussed an international investment court, notably at International Law Association conferences").

213 The Convention of the Settlement of Investment Disputes Between Host States of Arab Investments and Nationals of Other Arab States, June 10, 1974, reproduced in French in 1981 Rev. Arb. 348; Unified Agreement for the Investment of Arab Capital in the Arab States, Nov. 26, 1980, available at http://investmentpolicyhub. unctad.org/Download/TreatyFile/2394. See also Walid Ben Hamida, The Development of the Arab Investment Court's Case Law: New Decisions Rendered by the Arab Investment Court, 6 InT'L J. Arab Arb. 12 (2014).

214 See supra note 47 and accompanying text.

215 See infra section $\operatorname{IV}(\mathrm{F})(1)$ and accompanying footnotes.

216 The divisions would be composed of members randomly selected from the Tribunal, consisting of a roster with fixed term appointments created by the treaty parties. At least for a transitional period, the Tribunal members would be paid a monthly retainer complemented by the scheduled ICSID hourly fees when they serve on a Tribunal, and they would not be barred from working on arbitration cases. After the transitional period, they are to be paid a salary and hired on a full-time basis. See Negotiating Directives, supra note 209. Until the system becomes fully operationalized, the proposed Tribunal would retain a number of ISDS characteristics, raising questions regarding the extent of its differentiation from ISDS. See UN Office of the High Commissioner, supra note 48.

217 See. e.g., CETA, supra note 41, Art. 8.27(4).

218 Id. Art. 8.28.

${ }^{219}$ Id. Art. 8.30(1). 
by the parties that choose to join it. The EU's treaties, such as CETA, commit the parties to apply a multilateral mechanism once established. ${ }^{220}$

\section{Trade-offs of the multilateral investment court system}

As regards fairness, some commentators contend that a multilateral investment court system would be less fair for investors because states would control the nomination of judges and thus the judges would favor states. ${ }^{221}$ Other commentators object to the notion that fairness requires allowing private parties to choose their own judges when suing states, given the broader public policy interests are at stake. ${ }^{222}$ Arguably, when selecting permanent judges ex ante rather than ad hoc arbitrators ex post, treaty parties have a greater incentive to internalize their interests as capital-importers and -exporters and thus pick balanced judges, rather than pro-state or pro-investor ones, who are committed to upholding the treaty parties' agreement. ${ }^{223}$ For many skeptics of ISDS, a court should be better positioned to balance investor rights against other public policy goals, as reflected in the principle of a state's right to regulate. In addition, a court with an appellate mechanism is more likely to treat like cases alike, so that investors' claims will be treated more consistently (especially where the text of the applicable legal instruments is the same).

The proposed multilateral investment court system also provides greater opportunities than ISDS for repeat interaction with national courts. These interactions are more likely to give rise to a common understanding of legal obligations. If that occurs, then the court may be better positioned to advance rule-of-law norms within domestic governance. Nonetheless, since the proposed system is structured as a substitute for domestic courts (subject to reservations), it also is less likely than complementary mechanisms to place pressure on national governments to ensure the independence, impartiality, and quality of their domestic dispute settlement systems. ${ }^{224}$

Commentators also contend that a multilateral court system would be less biased than ISDS in favor of major powers, and in particular the United States. Gus Van Harten, for example, notes that under ICSID, the authority to appoint arbitrators that the parties do not designate, such as the chair of the tribunal, is vested in an official who is close to the U.S. government. ${ }^{225}$ The Convention empowers the chairman of ICSID's Administrative Council (i.e., the president of the World Bank, who always has been a U.S. national) to select

${ }^{220}$ See, e.g., CETA, supra note 41, Art. 8.29 ("Upon establishment of such a multilateral mechanism, the CETA Joint Committee shall adopt a decision providing that investment disputes under this Section will be decided pursuant to the multilateral mechanism and make appropriate transitional arrangements.").

221 See Schwebel, supra note 48.

222 See Gus Van Harten, A Case for an International Investment Court (Soc'y of Int'l Econ. L. Inaugural Conf., Working Paper No. 22/08, 2008), available at http://digitalcommons.osgoode.yorku.ca/cgi/viewcontent.cgi? article $=1258 \&$ context $=$ all_papers.

${ }^{223}$ Anthea Roberts, Would a Multilateral Investment Court be Biased? Shifting to a Treaty Party Framework of Analysis, EJIL: TALK! (Apr. 28, 2017), available at https://www.ejiltalk.org/would-a-multilateral-investmentcourt-be-biased-shifting-to-a-treaty-party-framework-of-analysis.

224 This feature, however, might be reconsidered if a multilateral convention were to be negotiated following developments in the UNCITRAL working group. See Roberts, supra note 1, at 418.

${ }^{225}$ Van Harten, supra note 222, at 17-18. ICSID only appoints arbitrators when the parties themselves appoint them or when the parties have not agreed on the Chair or another means to select the Chair, such as by the other two arbitrators. 
from among a roster of arbitrators the remaining arbitrator(s). In practice, this function is performed on the recommendation of ICSID's secretary-general, whom a former (acting) secretary-general of ICSID has accused of "paying heed" to the United States and other rich countries. ${ }^{226}$ Interestingly, the United States has never lost an ISDS case. ${ }^{227}$

From the perspective of resource allocation efficiency, if a permanent court is more deferential toward states because states appoint the judges, then, in theory, investors could be warier of investing, raising a state's cost of capital. Yet, for investment protection to be optimal, states should balance foreign investment with other social welfare goals, and tribunals should not privilege investor protection over those goals. Moreover, there is little reason to believe, and no empirical evidence to substantiate, that rational investors would be less likely to invest under a multilateral investment court system rather than ISDS—although the court could face backlog problems since it cannot expand the number of panels in response to a large number of new claims as the ISDS regime. In addition, although maintaining a permanent court has costs, ISDS may be just as expensive, especially since annulment proceedings are frequently used. Thus, institutional costs should be given limited weight in deciding between them (especially if the costs can be transferred partially to the disputing parties), although they could be a factor in relation to other alternatives. ${ }^{228}$

The proposed multilateral investment court system should have similar, although potentially not as robust, positive effects as ISDS on depoliticizing disputes. Permitting investors to take disputes directly could depoliticize them as compared to having them resolved through diplomatic confrontation. Yet, because states control the appointment of the judges, the process could become politicized, as seen in the crisis besetting the WTO's Appellate Body. ${ }^{229}$ Members of the international investment law community fear a similar attack on a potential investment court.

\footnotetext{
226 See Douglas Thomson, Is ICSID a "Monarchy"?, GLob. Arb. Rev. (2016) (citing Nassib Ziade, former secretary-general of ICSID). Both the president of the Bank and the secretary-general of ICSID have routinely been accused of bias in the practice of appointments. See Antonio R. Parra, The Development of the Regulations and Rules of the International Centre for Settlement of Investment Disputes, 22 ICSID REV.-FOR. INV. L.J. 55 (2007).

${ }^{227}$ In one infamous case, commentators broadly view the result as a function of political pressure. See, e.g., Jan Paulsson, Moral Hazard in International Dispute Resolution, Inaugural Lecture as Holder of the Michael R. Klein Distinguished Scholar Chair at the Miami University School of Law, at 6 (Apr. 29, 2010), available at http://www. arbitration-icca.org/media/0/12773749999020/paulsson_moral_hazard.pdf (citing a conference recording where the arbitrator admitted he "had met with officials of the U.S. Department of Justice prior to accepting the appointment, and that they had told him: "You know, judge, if we lose this case we could lose NAFTA." He remembered his answer as having been, "Well, if you want to put pressure on me, then that does it.").

228 See European Commission, State of the Union 2017: A Multilateral Investment Court, available at http:// trade.ec.europa.eu/doclib/docs/2017/september/tradoc_156042.pdf ("The interested parties would need to negotiate the budget and financing of the multilateral investment court. Like all other international organizations, the contracting parties would in principle finance the court. Its costs would depend on: the number of employed judges; the size of the secretariat; the number of contracting parties.").

${ }^{229}$ Gregory Shaffer, Manfred Elsig \& Mark Pollack, Trump Is Fighting an Open War on Trade. His Stealth War on Trade May Be Even More Important, Wash. Post (Sept. 27, 2017). See also Karen J. Alter, James T. Gathii \& Laurence R. Helfer, Backlash Against International Courts in West, East and Southern Africa: Causes and Consequences, 27 EUR. J. INT'L L. 293 (2016) (on the Zimbabwe government's blocking of the Tribunal for the South African Development Community after a decision against it); Dapo Akande, ICJ Elections 2017: UN General Assembly and Security Council Elect Four Judges to the ICJ but Fail to Agree on a Fifth, Yet Again! + Trivia Question, EJIL: TALK! (Nov. 11, 2017), at https://www.ejiltalk.org/icj-elections-2017-un-general-assemblyand-security-council-elect-four-judges-to-the-icj-but-fail-to-agree-on-a-fifth-yet-again-trivia-question.
} 
In terms of bias, depending on implementation details regarding the cost of access, transparency, and the process of nominating adjudicators, the proposed multilateral investment court system could better balance investors' legitimate expectations against state regulatory goals. It thus has the potential to correct some of the minoritarian biases associated with ISDS while also helping to counter majoritarian biases in domestic decision-making. Nonetheless, use of a permanent court would remain expensive, thus favoring those with high per capita stakes, such as large investors. If such potential bias raises concerns, the question remains: compared to what?

\section{F. International Adjudicatory Mechanisms as Complements}

A final adjudicative alternative is a system of complementarity under which domestic and international dispute settlement processes are linked. This alternative prioritizes the use and development of domestic institutions (courts or otherwise), which are first given the opportunity to decide the matter. An international adjudicatory body acts as a backdrop, which, depending on how the process is structured, potentially overrules, takes account, or provides guidance for the domestic determinations.

There are multiple ways to design complementary processes. We present three examples of existing international mechanisms that could motivate experimentation: (1) direct review of domestic administrative or judicial decisions by an international panel, as reflected in NAFTA Chapter 19; (2) independent review of compliance with international law commitments after the exhaustion of domestic judicial procedures, as before the European Court of Human Rights (ECtHR); and (3) referrals by national courts to an international court, as under the preliminary reference procedure of the CJEU. We then briefly note other variants that could be considered, such as abstention and certification, which are used in other contexts, including some federal jurisdictions.

\section{International review of domestic decisions}

One option involving complementarity is to provide for domestic decision-making up to a certain stage, subject to review by an international adjudicatory body. NAFTA review of antidumping and countervailing duty decisions by national administrative bodies provides an example. Chapter 19 of the trade agreement provides that the state of nationality of the foreign exporter may, or upon the exporter's request shall, request the establishment of a binational panel to review the final determination issued by the relevant authority of the NAFTA party. ${ }^{230}$ The binational panel, composed of five members from the two countries involved, can affirm, overrule, or remand agency determinations. The decisions are binding within the domestic jurisdiction and cannot be appealed to domestic courts. The process is complemented by an extraordinary challenge procedure where a NAFTA party can challenge a binational panel ruling on limited grounds, such as for manifestly exceeding its powers. ${ }^{231}$

\footnotetext{
${ }^{230}$ North American Free Trade Agreement, Art. 1904.5, Dec. 17, 1992, 32 ILM 289. See also David A. Gantz, Resolution of Trade Disputes Under NAFTA's Chapter 19: The Lessons of Extending the Binational Panel Process to Mexico, 29 L. \& Pol'y InT'L Bus. 297, 298 (1998).

${ }^{231}$ NAFTA, supra note 230, Art. 1904 The challenge is before a committee of three members from the three countries chosen from a fifteen-person roster. Id. Annex 1904.13 (Extraordinary Challenge Procedure).
} 
Under NAFTA Chapter 19, each party applies its domestic law, which it is free to amend at any time provided that its domestic law complies with WTO rules. ${ }^{232}$ WTO law, in turn, is enforced through interstate dispute settlement, which helps to clarify the meaning of the provisions. ${ }^{233}$ The binational panel's determination focuses exclusively on the correct application of the law by the domestic authority conducting the investigation, creating an international check on the domestic decision-making process. As a result, binational panels replace judicial review of national administrative decisions by domestic courts.

In theory, parties could adapt this process to provide for first-level judicial review before a national court, subject to appeal before an international tribunal. The ability to appeal judicial decisions to an international panel can check bias in national decision-making, but it also raises sovereignty concerns. Indeed, the current U.S. administration wants to terminate NAFTA Chapter 19, and others in the United States have questioned Chapter 19's constitutionality. ${ }^{234}$ Similarly, Belgium has asked the CJEU to issue an opinion on the compatibility of the investment court system under CETA with EU law, and the CJEU held in March 2018 that the provisions for ISDS in a BIT between EU member states are incompatible with EU law. ${ }^{235}$ The sovereignty concerns would become even more salient were an international body to overrule a domestic court's application of domestic law. Reflecting this concern, India's new model BIT provides that arbitral tribunals shall not have jurisdiction "to re-examine any legal issue which has been finally settled by any judicial authority of the Host State.”236

\section{International claims after domestic proceedings}

A second option is to permit a private party to bring a claim before an international adjudicatory body under international law, but only after exhausting domestic remedies. This approach differs from the first in that the international adjudicator does not apply domestic law, nor does it directly review or reverse a domestic administrative or judicial finding. Rather, the international mechanism applies international law and commences proceedings only after domestic law processes are completed.

The ECtHR exemplifies this approach. The court has jurisdiction to hear disputes filed by private parties as well as states under the European Convention of Human Rights (ECHR)

${ }^{232}$ Id. Art. 1902.2 (providing that amendments to domestic law must not be inconsistent with the GATT and antidumping and subsidy codes and any "successor agreement").

${ }^{233}$ For example, the United States lost a series of WTO cases in which countries challenged its practice of using "zeroing" to find dumping and inflate antidumping margins. Chapter 19 binational panels subsequently held against U.S. administrative findings that used zeroing. See, e.g., Article 1904 Binational Panel Review Pursuant to the North American Free Trade Agreement, Stainless Steel Sheet and Strip in Coils from Mexico: Final Results of 2004/2005 Antidumping Review, USA-MEX-2007-1904-01 (Apr. 14, 2010), available at http://www.worldtradelaw.net/nafta19/stainlessincoils-dumping-nafta19.pdf.

${ }^{234}$ Office of the United States Trade Representative, Summary of Objectives for the NAFTA Renegotiations, at 14 (July 17, 2017), available at https://ustr.gov/sites/default/files/files/Press/Releases/NAFTAObjectives.pdf (listing among the objectives of the NAFTA renegotiation: "Eliminate the Chapter 19 dispute settlement mechanism"). Scholars have contested whether use of Chapter 19 panels is constitutional, but it so far has withstood constitutional challenge. See, e.g., Alan B. Morrison, Appointments Clause Problems in the Dispute Resolution Provisions of the United States-Canada Free Trade Agreement, 49 WaSH. \& LeE L. Rev. 1299 (1992).

${ }^{235}$ See Belgium, Opinion (Opinion 1/17) on the Compatibility of CETA Investment Court System with EU Law; Slovak Republic v. Achmea B.V., Case C-284/16, paras. 56-60 (CJEU Mar. 6, 2018) (precluding ISDS under an agreement between the Netherlands and the Czech and Slovak Federative Republic because of its implications for the effectiveness of EU law).

${ }^{236}$ Model Indian BIT, supra note 44, Art. 14(2)(ii). 
and its Protocols against any of the forty-seven members of the Council of Europe. The ECtHR has heard investment law claims under the right to "property" enshrined in Article 1 of Protocol No. 1 of the ECHR. ${ }^{237}$ Most notably, the ECtHR heard a challenge relating to Russia's nationalization of the Yukos oil company, issuing a $€ 1.87$ billion award against Russia in 2014 — the largest award in the court's history—although Russia has yet to pay it. ${ }^{238}$

Article 35 of the ECHR requires the exhaustion of local remedies before a party may initiate a claim before the court. ${ }^{239}$ The rationale for the rule is to afford domestic authorities the opportunity to prevent or correct an alleged international law violation. A domestic court can, in the process, apply the international standard and internalize it as part of domestic law. When praising the rule of exhaustion of local remedies, Louis Sohn and Richard Baxter emphasized the benefits of putting domestic courts in the front line to oversee compliance with international law obligations and enhance international law's effectiveness. ${ }^{240}$

The use of exhaustion represents a form of "subsidiarity," a principle which favors decisionmaking at the local level where possible. ${ }^{241}$ The ECtHR complements the subsidiarity principle with the principle of a "margin of appreciation," under which the court grants local decision-makers a degree of discretion in applying ECHR standards in light of local contexts and conditions. ${ }^{242}$ The court varies its application of the margin as a function of the sufficiency and effectiveness of domestic procedures and remedies. ${ }^{243}$ In doing so, it arguably provides an incentive for domestic authorities to improve the domestic rule of law.

237 See generally, Christian Tomuschat, The European Court of Human Rights and Investment Protection, in International Investment Law for the 21st Century (Christina Binder, Ursula Kriebaum, August Reinisch \& Stephan Wittich eds., 2009).

${ }^{238}$ OAO Neftyanaya Kompania Yukos v. Russia, App. No. 14902/04, Judgment on Just Satisfaction (Eur. Ct. H.R. 2014).

${ }^{239}$ Convention for the Protection of Human Rights and Fundamental Freedoms as Amended by Protocols Number 11 and Number 14, Art. 35, June 1, 2010, CETS No. 194 [hereinafter ECHR]. The complainant only needs to raise the issue implicitly before local courts, or address it in terms of substance, in which case the exhaustion rule is satisfied. Only in very limited circumstances may an affected party be exempted from the requirement of exhausting local remedies.

${ }^{240}$ Louis B. Sohn \& R. R. Baxter, Draft Convention on the International Responsibility of States for Injuries to Aliens (1961), reprinted in Recent Codification Of The Law Of State Responsibility For Injuries To Aliens 262 (F. V. Garcia-Amador, Louis Sohn \& Richard Baxter eds., 1974) (noting how "exhaustion of local remedies" "forc[es] the maximum number of cases involving aliens into domestic courts . ., with consequent beneficial effects for the legal protection of aliens [because of] a wider incorporation of international standards into municipal law").

${ }^{241}$ On subsidiarity, see Markus Jachtenfuchs \& Nico Krisch, Subsidiarity in Global Governance, 79 L. \& Contemp. Probs. 1, 6-7 (2016). On its application to investment law, see generally, René Urueña, Subsidiarity and the Public-Private Distinction in Investment Treaty Arbitration, 79 L. \& ConTemP. ProBs. 99, 99-100 (2016) (arguing that "the demand for subsidiarity [in ISDS] is a function of the public-private divide in investment law," with those focusing on the private nature of investment arbitration paying less heed to subsidiarity).

242 See Andrew Legg, The Margin Of Appreciation In International Human Rights Law: Deference And Proportionality (2012); Julian Arato, The Margin of Appreciation in International Investment Law, 54 VA. J. INT'L L. 545 (2014).

243 See Thomas Kleinlein, Consensus and Contestability: The ECtHR and the Combined Potential of European Consensus and Procedural Rationality Control, 28 EUR. J. INT'L L. 871, 872 (2017). 


\section{Interpretation at the request of national courts}

Under a third option, domestic courts could be required to submit questions to an international adjudicatory body concerning an issue of international law that has not been clearly settled. The response by the international body - likely a court—is binding as a matter of law. Unlike under the first and second complementarity options, it is the national court that ultimately resolves the dispute between the parties. The national court decides all factual issues and it applies international law (as clarified by the international court) to the facts of the case.

The European Union uses such an approach for EU law, which is part of the national law of EU member states. National courts may (and courts of final review must) ask the CJEU for a preliminary ruling whenever a question of EU law is raised unless the CJEU has already pronounced on an identical matter or there is no reasonable doubt about the appropriate interpretation. ${ }^{244}$ The European Union backs this system with a parallel procedure pursuant to which member states or the European Commission can challenge a state's failure to comply with EU law. 245

\section{Other variants of complementarity}

The complementarity mechanisms described above could be tailored to the investment context. For example, a treaty could require the use of local remedies for a significant period of time before international adjudication can be triggered — such as the five-year period prescribed in India's new model BIT ${ }^{246}$ — and an arbitral tribunal could be granted the discretion to stay the arbitration and extend such period where appropriate. An investment treaty also could grant private parties the right, following the exhaustion of local remedies, to petition an international commission that is empowered to bring investment claims on their behalf before an international court. The American Convention on Human Rights, which contains a right to property, includes such a mechanism. ${ }^{247}$

\footnotetext{
${ }^{244}$ Although a referral to the CJEU may be requested by one of the parties involved in the dispute, the decision to do so rests with the national court. The request stays national proceedings until the CJEU issues its ruling. The ruling has the force of res judicata, and its clarification of the law is binding on all national courts in the European Union. See Consolidated Version of the Treaty on the Functioning of the European Union, Art. 34, May 9, 2008, O.J. (C 115) 47, Art. 267, available at https://eur-lex.europa.eu/resource.html?uri=cellar:41f89a28-1fc6-4c92b1c8-03327d1b1ecc.0007.02/DOC_1\&format=PDF; Damian Chalmers, Gareth Davies \& Giorgio Monti, European Union Law: Text and Materials 188 (3d ed. 2014). In practice, lower EU courts have made the bulk of preliminary references. See Karen Alter, Establishing the Supremacy of European Law: The Making of an International Rule of LaW in Europe 49-51 (2001).

245 Chalmers, Davies \& Monti, supra note 244, at 337-77.

${ }^{246}$ Model Indian BIT, supra note 44, Art. 14(2)(ii).

${ }^{247}$ Private parties may petition the Inter-American Commission on Human Rights, which can refer their case to the court. The court also may issue advisory opinions in response to requests from member states or the commission regarding the interpretation of the convention, including whether domestic laws and proposed domestic legislation are compatible with the convention. Article 21.2 of the Convention provides for the protection of property rights. See Claudio Grossman, The Inter-American System and its Evolution, 2 INTER-Am. \& EUR. Hum. RTS. J. 49 (2010). See, e.g., Saramaka People v. Suriname, Merits and Reparations, Judgment, Inter-Am. Ct. H.R. (ser. C) No. 172, para. 127 (2007) (stating "the Court has previously held that . . . a State may restrict the use and enjoyment of the right to property where the restrictions are: a) previously established by law; b) necessary; c) proportional; and d) with the aim of achieving a legitimate objective in a democratic society").
} 
Other variants could build on domestic federal jurisdictions and private international law. For example, an international tribunal could refer a question of domestic law that arises in an investment dispute to a domestic court. Some jurisdictions, such as the United States, use an analogous mechanism whereby a federal court abstains from deciding a matter where state law is unclear until it is clarified by a state court, or refers the question to the state's highest court (a procedure known as "certification"). ${ }^{248}$ Many well-known investment disputes illustrate how this procedure could be useful. For example, in his dissent in Bilcon v. Canada, Donald McRae found that the tribunal decided an issue under Canadian law that should have been decided by Canadian courts. ${ }^{249}$ A similar issue arose in the Metalclad case, which involved the power of local Mexican authorities under the Mexican constitution. ${ }^{250}$ In private international law, national courts also can stay proceedings out of international comity while another court decides the issues, basing their decisions on such factors as respect for the acts of foreign courts, fairness to disputants, and efficiency. ${ }^{251}$

Finally, one can imagine less formal means that facilitate the use of domestic dispute settlement in the first instance. NAFTA gives investors up to three years to trigger arbitration, and thus investors may pursue local remedies until that time. ${ }^{252}$ CETA goes further. Like NAFTA, it establishes a three-year statute of limitations if no domestic remedies are pursued. However, if domestic remedies are pursued, then the investor has two years to commence arbitration after they are completed, subject to a maximum of ten years from the initial measure. ${ }^{253}$ In each case, once an investor initiates arbitration, it may no longer bring or continue its claims for damages before a domestic administrative tribunal or court. In this way, investors are granted time to resolve matters within domestic legal systems without pressure to trigger ISDS. There is some evidence that this mechanism may lead to more reliance on domestic courts than fork-in-the-road provisions under which an investor must exclusively use either local remedies or ISDS. ${ }^{254}$

248 See Erwin Chemerinsky, Federal Jurisdiction 831-35, 860-62 (7th ed. 2016) (discussing abstention and certification).

${ }^{249}$ Bilcon of Del., Inc. v. Gov't of Can., Case No. 2009-04, 9 51, paras. 2, 42 (Perm. Ct. Arb. 2015) (McRae, dissenting), at https://www.italaw.com/sites/default/files/case-documents/italaw4213.pdf (maintaining that "it applies the standard in a way that it is met simply by an allegation of a breach of Canadian law," and finding that " $t]$ hey could have taken the matter to the Federal Court of Canada, which could have reviewed the decision and perhaps overturned it").

${ }^{250}$ Metalclad, supra note 123, paras. 105-06 (basing its decision on its finding that "the Municipality acted outside its authority" because "the exclusive authority for siting and permitting a hazardous waste landfill resides with the Mexican federal government"-i.e., an issue of Mexican law that, in fact, was in dispute).

${ }^{251}$ See, e.g., Royal and Sun Alliance Ins. Co. of Canada v. Century Int'l Arms, Inc., 466 F.3d 88 (2d. Cir. 2006). Cf. European Union Regulation No. 1215/2012 on Jurisdiction and the Recognition and Enforcement of Judgments in Civil and Commercial Matters (Recast), Art. 29 (creating a first-in-time rule except where the parties otherwise have stipulated a court that has jurisdiction). For a general discussion on the complex relationship between domestic courts and ISDS, see, Christopher Schreuer, Interaction of International Tribunals and Domestic Courts in Investment Law, in Contemporary Issues in InTERnational Arbitration and Mediation: The Fordham Papers 2010, at 71 (A. W. Rovine ed., 2011).

252 NAFTA, supra note 230, Arts. 1116, 1117.

253 CETA, supra note 41, Art. 8.19.6.

${ }^{254}$ For discussion, see Sergio Puig, Investor-State Tribunals and Constitutional Courts: The Mexican Sweeteners Saga, 5 MeXICAN L. REv. 199 (2013) (noting use of Mexican courts under the NAFTA model, known as known as a "no-U-turn" (or waiver) model). 


\section{Trade-offs of complementarity mechanisms}

The above examples of complementarity operate in different ways, but they uncover common lessons. Most importantly, complementarity mechanisms prioritize the enhancement of the rule of law within domestic jurisdictions. They recognize domestic authorities as the primary guardians of achieving the rule of law and fairness toward investors and other constituencies, but subject to an international accountability mechanism. In the process, they can enhance legal certainty and uniform application of the law. By empowering domestic courts to oversee compliance with legal obligations (which directly or indirectly reflect international law ones), complementarity mechanisms can broaden international law's reach. ${ }^{255}$ There is some (at least preliminary) empirical evidence that they do so better than the alternative of using international tribunals as substitutes. ${ }^{256}$ These mechanisms can provide better assurance to all investors - large and small, foreign and domestic - thus reducing the cost of investment capital within the state. If the processes avoid significantly greater delay than the ISDS or proposed international court system — for instance, through tight standardized schedules (as under the WTO) - they should provide assurance for foreign investors. In addition, because complementarity mechanisms trigger interaction between national and international bodies, they can facilitate greater congruence between international and national norms. ${ }^{257}$ As a result, states may be less inclined to politicize a conflict.

There are nonetheless potential disadvantages with this alternative. Some argue that there is a level of expertise lost through the application of international law by domestic judges with general jurisdiction. ${ }^{258}$ Others contend that empowering domestic adjudicatory processes to apply international law will catalyze new judicial politics domestically. ${ }^{259}$ Increased interaction could lead to politicization and friction between international and domestic courts as well, especially if an international tribunal were to expressly overrule a domestic legal system's

\footnotetext{
${ }^{255}$ Van Aaken, supra note 204, at 754 (arguing that "[I[f investment law is a kind of international administrative law, a harmonious combination and an alignment of the internationalized system of state liability and the national systems seems desirable"); see also Richard C. Chen, Bilateral Investment Treaties and Domestic Institutional Reform, 55 Colum. J. Transnat'l L. 547 (2017).

256 See Jennifer L. Tobin \& Susan Rose-Ackerman, When BITs Have Some Bite: The Political-Economic Environment for Bilateral Investment Treaties, 6 REv. INT'L ORG. 1, 5 (2011) (providing empirical evidence that that international dispute settlement mechanisms have more impact when they complement an existing set of effective domestic institutions); Ginsburg, supra note 189, at 119 (providing empirical evidence that ISDS may "reduce courts' incentives to improve performance by depriving key actors from a need to invest in institutional improvement”).

${ }^{257}$ Tom Ginsburg \& Richard McAdams, Adjudicating in Anarchy: An Expressive Theory of International Dispute Resolution, 45 William \& MARY L. ReV. 1229 (2004) ('First, adjudicative expression may construct 'focal points' that clarify ambiguities in the convention. Second, adjudicative expression may provide 'signals' that cause parties to update their beliefs about the facts that determine how the convention applies."); RiCHARD McADAMS, THE EXPressive Powers of Law: Theories And Limits (2015).

${ }^{258}$ August Reinisch, The International Relations of National Courts: A Discourse on International Law Norms on Jurisdictional and Enforcement Immunity, in THE LAW OF INTERNATIONAL RELATIONS: Liber AMicorum HaNSPETER NeuHold 289, 307 (August Reinisch \& Ursula Kriebaum eds., 2007)

259 See Curtis A. Bradley, The Treaty Power and American Federalism, 97 Mich. L. Rev. 390, 440-43 (1998) (questioning whether domestic courts should play an active role in enforcing international commitments in light of the opaque nature of the treaty-making process, and the vagueness of many of the treaty provisions that pose federalism issues).
} 
highest court. ${ }^{260}$ Complementarity mechanisms - depending on their design-also could create significant delay and increase the cost of dispute settlement. ${ }^{261}$ If so, this could prejudice investors, which could be deterred from investing. ${ }^{262}$

From the vantage of comparative institutional analysis, the potential complexity, delay, and increased cost of complementarity mechanisms create a risk of minoritarian bias, since large investors with large stakes are better positioned than others to use such mechanisms. In addition, because investors no longer would have direct access to an international body, some could relinquish justified claims because of the increased costs, and thus local majoritarian bias would not be countered.

The key disadvantage of these mechanisms is that their effectiveness depends on the good faith of national courts. Reference procedures, for example, depend on whether national courts refer questions to the international body, since such referrals may not be under the parties' control. If national courts are not independent of the government, then references may not occur. Exhaustion of local remedies rules function only when domestic courts provide real access to justice, as opposed to endless delay in favor of the state. Without some level of trust in national courts, complementarity mechanisms could play into the hands of states that use the prospect of endless delay to extract concessions from aggrieved investors.

Nonetheless, complementarity mechanisms facilitate the ability of all stakeholders to advance claims and counterclaims regarding an investment dispute because they prioritize the use of domestic mechanisms. They thus can be less one-sided and asymmetric than international adjudicatory mechanism such as ISDS or a multilateral investment court system used as substitutes. In this way, they can better protect against potential minoritarian bias in favor of high-stakes investors, which is a common criticism of ISDS. As counter-majoritarian institutions, domestic courts can also check majoritarian biases in domestic decision-making, while being better situated to account for domestic local contexts.

As previously discussed, domestic courts can also be subject to bias. In the case of complementarity mechanisms, however, these biases can be checked. An international tribunal is held in reserve to help support and assure that domestic processes function as intended. In this way, complementarity mechanisms can address the relative deficiencies of relying solely on domestic mechanisms or, alternatively, solely on international adjudicatory processes.

In the end, the effectiveness of complementarity mechanisms depends on the existence of some level of judicial independence and impartiality in the domestic jurisdiction, combined with some level of trust across the domestic/international divide. Where these conditions are present, complementarity mechanisms can be both fair and effective. Moreover, they can work dynamically to enhance rule-of-law protections over time. Where these conditions

\footnotetext{
${ }^{260}$ Apparently, this was a reason why the European Commission, in the end, did not require exhaustion of local remedies in its proposal for a multilateral investment court system. Interview with Official of the European Commission, supra note 155.

${ }^{261}$ Cf. Anthony Sinclair, ICSID Arbitration: How Long Does It Take?, 4 GLoB. Arb. Rev. (2009) (reporting that the average length of an ICSID arbitration is 3.6 years); BONNITCHA, POULSEN \& WAIBEL, supra note 87, ch. 3 (finding that "this is more than twice the duration for litigation in domestic courts in selected developed countries").

262 Christoph H. Schreuer, Do We Need Investment Arbitration?, 11 Transnat'L Disp. Mgmt. 1, 10 (2014) (arguing that "the primary victims of [increase of cost and time] would be small and medium sized investors").
} 
are lacking, then complementarity mechanisms could be dysfunctional or at least increase the cost of dispute settlement. As in all cases, the imperfections of these complementary options must be weighed against those of other institutional alternatives.

\section{Conclusion}

While institutional choice is always contextual and thus difficult, comparative institutional analysis is essential because all institutional options are imperfect and subject to trade-offs. Market options may not be available in many situations, especially for small- and medium-sized investors. Domestic mechanisms may not be independent or impartial, and thus lack basic rule-of-law protections. Diplomacy tends to favor powerful states, as well as influential firms that lobby them. Interstate dispute settlement can politicize disputes and still be tilted in favor of powerful actors, whether they be states or large corporations that have privileged access to state officials.

For these reasons, many states turned to what is now the most frequently used mechanism-ISDS - but it too has many deficiencies. The system of appointment of arbitrators creates perverse incentives; there is no appeal mechanism to provide for consistency and a check on poor decisions; and inconsistent decisions made by ad hoc tribunals limit the law's expressive value. A multilateral investment court system seems better on many counts. Yet it also is remote from domestic publics and its decisions could be resisted on sovereignty grounds.

In sum, it is difficult to decide in the abstract which institutional option is preferable. The primary goal, in our view, should be supporting the domestic rule of law. Thus, we highlight the importance of complementarity as an institutional option, an attribute that neither the current ISDS system nor the proposed multilateral investment court system prioritizes, although they could be adapted to do so, including through the current UNCITRAL reform process. From this perspective, national courts should be the first-line actors for resolving disputes, and other institutional mechanisms should provide incentives for enhancing the rule of law.

Contexts differ across states, and choices should depend on those contexts. Where basic rule-of-law norms are protected, the costs of an additional international system of review may not be worthwhile. Rather, reliance may be better placed on national courts, backed by market mechanisms. Where a state, in contrast, lacks independent, impartial, quality courts, an international mechanism that provides for investor standing to bring claims is of much greater importance. In some contexts, states may prefer not to include a system of exhaustion of local remedies so as to streamline the process. A state can then provide greater assurance to investors. In this context, a permanent court with an appellate mechanism appears to be a superior model to ISDS because it would more likely be attentive to a state's public policy interests, and it would provide for greater consistency and coherence across decisions.

Including national courts in decision-making offers advantages for building the domestic rule of law dynamically over time. For transitional states, ones where courts are developing in their professionalism and independence, a system of complementarity seems more appropriate. When rule-of-law norms are advanced through international law and become embedded 
in domestic governance, they can contribute to the creation of a broader transnational legal order. $^{263}$

We do not claim to have found an institutional option that is best across all contexts or through time. Adopting a legal realist perspective, ${ }^{264}$ the primary goal of this Article is to present and apply an analytic framework that helps to clarify the trade-offs of different institutional options for international investment law. The option chosen will be a function of context involving particular factors, such as a state's capital endowment, market size, ideology, institutional development, and historical legacy. ${ }^{265}$ The tailoring of institutional choice can be met by what Roberts describes as ongoing pluralism and flexibility in the architecture of institutional mechanisms. ${ }^{266}$ Looking forward, our analysis reveals that the international investment regime should not simply rely on ISDS. Nor should it be replaced with a multilateral investment court system that applies to all countries unless such system provides for flexibility, such as through opt out and opt in provisions. ${ }^{267}$ Maintaining flexibility will be key, a flexibility that permits states facing different challenges to select from a menu of imperfect international alternatives in light of their trade-offs. That flexibility should include experimentation with different complementarity mechanisms.

263 See Jothie Rajah, 'Rule of Law' as Transnational Legal Order, in Terence Halliday \& Gregory Shaffer, Transnational Legal Orders (2015).

${ }^{264}$ See Victoria Nourse \& Gregory Shaffer, Varieties of New Legal Realism: Can a New World Order Prompt a New Legal Theory, 95 Cornell L. Rev. 61 (2009); Gregory Shaffer, The New Legal Realist Approach to International Law, 28 LEIDEN J. INT'L L. 189 (2015).

${ }^{265}$ In future work, we will address how these factors operate in the investment context.

${ }^{266}$ Roberts, supra note 1, at 431 (noting the possibility of "open architectural approaches that permit differently situated states to sign up for new multilateral approaches or institutional mechanisms").

267 The opt-in provisions, for example, could include state-to-state or investor-state dispute settlement, as well as different complementarity mechanisms. UNCITRAL often develops flexible legal instruments that incorporate different options. See Susan Block-Lieb \& Terence C. Halliday, Global Lawmakers: International Organizations in the Crafting of World Markets 80-82, 233-36, 257-59, 396-97 (2017). Similarly, the WTO Trade Facilitation Agreement creates different categories of obligations that become binding on different members at different times, including as a function of receipt of technical assistance. It provides an example of flexibility mechanisms that serves as a template for new proposals before the WTO, including regarding investment. See WTO, Trade Facilitation Agreement, Special and Differential Treatment Provisions for Least Developed Countries (LDC), at https://www.wto.org/english/tratop_e/tradfa_e/tfa_ldc_brochure_e.doc. 